\title{
Deividas Šlekys
}

Vilniaus universiteto Tarptautiniu santykiu ir politikos mokslu institutas

Generolo Jono Žemaičio Lietuvos karo akademija

\section{Intelektualinè refleksija: civilių ir kariškių santykiai Lietuvoje}

Civilių ir kariškių santykiai Lietuvoje turi rimtų defektų, kurie atsirado realizuojant vakarietiškus karinių pajègų kontrolès modelius. Atgavus nepriklausomybę Lietuvos laukè sudètingas ir sunkus uždavinys kuriant vakarietišką krašto apsaugos sistemą. Vienu metu reikẻjo vykdyti dvi skirtingas politines programas: kurti funkcionuojančias karines pajegas ir teisinę-institucinę struktūrą, kuri leistų užtikrinti demokratinę civilinę ginkluotųjų pajėgų kontrolę. Tačiau civilinė kontrolè yra ne tik atitinkami teisiniai aktai, institucijos. Nemažiau svarbi yra ir intelektualinė refleksija, kurios metu turètų būti keliami fundamentalūs klausimai: kas yra karas, kaip keičiasi karybos pobūdis, kaip tai veikia ir keičia Lietuvos sąjungininkų gynybos politiką, mūsų supratimą ir politinius karinès srities sprendimus. Tokio pobūdžio klausimų kèlimas karinių pajègų viduje ir didesnèje (civilių) bendruomenèje yra būtina sąlyga turèti efektyvią ir lanksčią civilinę kariškių kontrolę. Žvelgiant iš šios perspektyvos būtų galima teigti, kad Lietuva sèkmingai pritaikè institucinę struktūrą, tačiau antrojo etapo - kokybiško turinio ir diskusijų karine tematika skatinimas stringa ir nèra plètojamas. Tokia situacija susiklostė, nes perimti vakarietiški modeliai patys turi nemenkų defektų. Juose per daug yra koncentruojamasi ị institucinę struktūrą (formą), skiriama mažiau dèmesio turiniui. Lie-tuva šiuos modelius perėmè su trūkumais. Todèl šiuo straipsniu siekiama atlikti Lietuvos atvejo analizę ir jos pagrindu pasiūlyti tam tikrą pagrindinių civilių ir kariškių santykių modelių reviziją.

\section{Ivadas}

Atkūrusi nepriklausomybę Lietuva karines pajègas ir politinę-pilietinę jų kontrolès tradiciją kūrè nuo nulio. Kariuomenè yra specifinè institucija, tam tikra prasme valstybė valstybejje. Todèl nesvarbu, koks režimo tipas, visose valstybèse civiliai siekia kontroliuoti kariškius. Demokratinès valstybès, j kurių bendruomenę Lietuva įstojo, turi gana ilgą sąrašą kriterijų, leidžiančių užtikrinti šią kontrolę: kariai negali būti politinių partijų nariais ir siekti politinių postų, gynybos ministras privalo būti civilis ir t. t. Kaip ir daugelyje kitų sričių, Lietuva nekūrẻ savų modelių, o perèmè vakarietiškus. Per pirmąji ne-

\footnotetext{
"Dr. Deividas Šlekys - Vilniaus universiteto Tarptautinių santykių ir politikos mokslų instituto ir Generolo Jono Žemaičio Lietuvos karo akademijos lektorius. Adresas korepondencijai: Vokiečiu g. 10, 01130 Vilnius; tel. (8 5) 25 14130, el. paštas: deividas.slekys@tspmi.vu.lt.
} 
priklausomybės dešimtmetị šalyje lankèsi ir patarinëjo įvairūs mokslininkai, ekspertai, politikai ir karininkai. Todèl būtų galima drąsiai teigti, kad Lietuva sẻkmingai perèmè vakarietišką institucinị-teisinį civilių ir kariškių modelį. Šiuo metu šalyje funkcionuoja aiški teisinè bazè, reguliuojanti kariuomenès vidaus gyvenimą, jos veiklą, funkcijas ir šios institucijos santykius ir pavaldumą civilinei šalies vadovybei. Šalies politiniame gyvenime yra ịvardijamos ịvairios problemos ir grèsmès, tačiau jų sąraše nerasime punkto apie karinio perversmo galimybę. Tokia A. Smetonos režimo laikais ịprasta situacija yra tiesiog sunkiai ịsivaizduojama ir suvokiama šių dienų Lietuvoje.

Kita vertus, tai, kad nėra kalbama apie karinio perversmo galimybę, nereiškia, jog civilių ir kariškių santykiai yra kokybiški ir efektyvūs. Čia ir kyla įvairių iššūkių. Vakarietiški modeliai, kaip vèliau matysime, labiau akcentuoja šios kontrolès teisinių ir politinių institucijų sandaros svarbą. Tačiau mažesnis dèmesys skiriamas modelio turiniui ir kokybès užtikrinimui. Šiuo atveju neužtenka gerai veikiančių institucijų ir ịstatymų. Reikia, kad būtų atitinkamas suvokimas, kultūra ir veiklos tradicija. Tik tokiu atveju mes galime kalbèti apie funkcionuojančius civilių ir kariškių santykius. O kad būtų užtikrintas kokybiškas turinys, būtina intelektualinė refleksija. Kariuomenès nariai, ypač karininkai, privalo nuolatos reflektuoti savo veiklą. Priešingu atveju, nesuvokdami karo ir karybos kompleksiškumo, jie bus nepajègūs pateikti kokybiškų rekomendacijų vadovybei ir visuomenei. O pastarieji, turédami silpną intelektualinès refleksijos kariniais klausimais tradiciją, nebus pajègūs suvokti kariuomenès pasiūlymų kokybès, o tai gali vesti prie netinkamų politinių sprendimų.

\section{Vakarietiško civilių ir kariškių modelio revizija}

Prancūzijos premjeras Clemencau yra pasakęs, kad „karas yra per daug svarbus dalykas, jog būtų paliktas generolams prižiūrèti“. ${ }^{1}$ Tačiau vertètų paklausti, ar tokio pobūdžio klausimai turi būti užduodami ir aptariami tik civilių: ar ateities karai bus tokie, kokius matème paskutinị dešimtmetị Irake ir Afganistane? Gal jie labiau primins tragiškus pilietinius karus, vykusius Balkanuose ir Ruandoje? O pagaliau gal ateityje dominuos tokie konfliktai, koks vyko tarp Rusijos ir Gruzijos 2008 m. ir 2014-2015 m. Ukrainoje?

Visais šitais galimais scenarijais pateikiamos labai skirtingos ateities karybos vizijos, kurioms pasirengti reikia skirtingų kariuomenès tipų, ginklų sistemų, karinio parengimo ir mokymo. Žvelgiant ị karų istoriją ir dabarties

\footnotetext{
${ }^{1}$ Jackson H. J., Clemencau and the Third Republic. London: Hodder \& Stoughton, 1948, p. 228.
} 
konfliktus būtų galima teigti, kad greičiausiai vienu metu egzistuos visi šie karo tipai. Gynybos finansavimo ir politinė realybė vers išskirti prioritetus ir labiau akcentuoti vieną ar kitą ateities karų viziją. Su šia dilema susiduria visos valstybės ir visos jos savaip ją sprendžia. Tačiau svarbiausia, kad šiose diskusijose ir priimant sprendimus turi dalyvauti abi pusès. Kokybiškas dialogas įmanomas tik tada, kai egzistuoja kritinè refleksija šiais klausimais. Kita vertus, nereikia turèti pranašo gebẻjimų, kad būtų galima pamatyti, kad tokia prieštaringa būklè sukuria sudètingų ir sunkių galvosūkių civilių ir kariškių santykių srityje.

Demokratinèse valstybèse egzistuoja požiūris, jog kelti klausimus apie karinių priemonių naudojimą tarptautinèje politikoje yra ne karių darbas. Ši prerogatyva yra išskirtinai civilių privilegija. Ją labai taikliai iliustruoja Didžiosios Britanijos premjero Davido Camerono žodžiai, pasakyti Libijos operacijos metu $2011 \mathrm{~m}$. Reaguodamas ị aukščiausių karinių pajègų vadų nuomonę apie karinès kampanijos eigą jis teigè, kad: „Jūs (karinés pajegos - D. Š.) užsiimkite kariavimu, o aš pasirūpinsiu kalbẻjimu. “2 Paprastai tariant, britų premjeras primygtinai rekomendavo karinei vadovybei neužsimti politika, o dirbti savo darbą - kariauti. Reikia pastebèti, kad tokia Camerono pozicija nepagerino jo santykių su karininkija, o įtakingi karo studijų ekspertai negailëjo kritikos britų premjerui. ${ }^{3}$ Laikomasi nuomonès, kad tokia premjero pozicija buvo labai nekonstruktyvi ir gali ilgai turèti neigiamų pasekmių.

Taigi turime užduoti klausimą, koks turètų būti civilių ir kariškių santykių modelis, kuris leistų vykti konstruktyviam dialogui. Žinomas amerikiečių politikos mokslų atstovas Peteris Feaveris aprašo paradoksalią situaciją. Jis teigè: „kadangi mes bijome kitu, mes sukuriame prievartos instituciją, skirtą mus apginti, tačiau tuo pačiu metu mes pradedame bijoti šios institucijos, kurią sukūrẻme, kad mus gintų “4 Būtų galima drąsiai teigti, kad šis paradoksas atskleidžia esmines priežastis, kodèl civilių ir kariškių santykiai yra tokie svarbūs kalbant apie valstybès politinę-institucinę sandarą. Nesvarbu, koks būtų režimas ir politinè santvarka, visi jie nepasitiki savo karinèmis pajėgomis ir nori jas kontroliuoti, kad jos neịvykdytų karinio perversmo ar kitaip nepradè-

\footnotetext{
${ }^{2}$ Norton-Taylor R., "Defence Chiefs Must Be Called to Account," The Guardian, accessed February 10, 2015, http://www.theguardian.com/news/defence-and-security-blog/2011/aug/16/armed-forces-cameron; [žiūrèta 201501 30]; John Ingham, Defence Editor, "You Do the Fighting, I'll Do the Talking David Cameron Tells Military," Express.co.uk, June 22, 2011, http://www.express.co.uk/news/uk/254220/You-do-thefighting-I-ll-do-the-talking-David-Cameron-tells-military [žiūrèta 201502 01].

${ }^{3}$ Strachan H., The Direction of War : Contemporary Strategy in Historical Perspective. Cambridge: Cambridge University Press, 2013 m., pp. 74-75.

${ }^{4}$ Feaver P. D., “The Civil-Military Problematique: Huntington, Janowitz, and the Question of Civilian Control," Armed Forces \& Society 23, No. 2 (Winter 1996), p. 149.
} 
tų kontroliuoti valstybès. Tik skirtingi politiniai režimai taiko skirtingus būdus ir priemones šiai kontrolei igyvendinti.

Visos diskusijos apie tai, kokie turètų būti civilių ir kariškių santykiai prasideda nuo dviejų autorių Samuelio Huntingtono ir Morriso Janowitzo idèjų aptarimo. Jų idèjos padejo pamatus dviem skirtingoms interpretacijų mokykloms, kurios pastaruosius 50 metų dominuoja karo sociologijos disciplinoje. Reikia iš karto pabrěžti, kad dauguma diskusijų sukasi apie JAV. Tačiau Vakarų valstybès perèmė ir taiko šias JAV reikmėms pasiūlytas idejas. Ne išimtis ir Lietuva.

Minètų dviejų autorių pasiūlyti modeliai buvo ne abstraktus intelektualinis žaidimas. Jie bande spręsti svarbų Šaltojo karo laikų JAV vidaus politikos klausimą: kaip integruoti karines pajegas ị šalies politinę sistemą. Gal tai mažai žinoma, tačiau tradiciškai amerikiečiai labai neigiamai ir atsargiai žiūrejo ir žiūri ị nuolatinių, reguliarių karinių pajegų egzistavimą. Tai tradicija, kuri egzistuoja nuo pat valstybès ịkūrimo pradžios. ${ }^{5}$ Yra bijoma, kad didesnè kariuomenè sustiprins centrinès valdžios, t. y. prezidento, galias kitoms institucijoms (Kongreso ir teismų), ivvels valstybę i nereikalingus konfliktus ir taip pamažu sugriaus demokratinę JAV santvarką. Iki II pasaulinio karo pradžios nebuvo poreikio iš esmès persvarstyti civilių ir kariškių santykius reguliuojančius įstatymus, institucinę sandarą. Tačiau II pasaulinio karo metais labai išaugusi kariuomené, jam pasibaigus, priešingai nei po JAV pilietinio ir I pasaulinio karo, nebuvo žymiai sumažinta. Dèl prasidejjusio Šaltojo karo JAV buvo priverstos laikyti didelę taikos meto kariuomenę. Tai buvo kokybiškai nauja politinė situacija. Egzistuojanti politine sistema turejjo sugalvoti, kaip integruoti šį naują žaideją i savo gretas. Toks buvo politinis kontekstas, kuriame Hungtintonas ir Janowitzas kūrè savo teorijas.

Huntingtonas savo veikalą Sodier and the State pradeda nuo Clausewitzo idejų analizès. Jo pasiūlyto modelio atspirties taškas yra Clausewitzo mintys apie karą kaip politikos instrumentą. Taip interpretuodamas Clausewitzą, amerikiečių mokslininkas teigia, kad politinè dimensija visada yra aukščiau už karinę ir todèl kariškiai turi paklusti politikams ir vykdyti jų nurodymus. ${ }^{6}$ Karinès pajègos nedalyvauja priimant politinius sprendimus. Jos tik vykdo paskirtas politines užduotis.

Problema, kurią Huntingtonas matė tiek JAV, tiek Europos valstybių, ypač Vokietijos, istorijoje buvo ne tiek pati kariuomenè ir jos ambicijos, kiek

\footnotetext{
${ }^{5}$ Millett A. R., Maslowski P., For the Common Defense: a military history of the United States from 1607 to 2012. New York: Free Press, 2012.

${ }^{6}$ Samuel P Huntington, The Soldier and the State. The Theory and Politics of Civil-Military Relations (Cambridge [Mass.]: The Belknap Press of Harvard University Press, 2003), p. 10.
} 
politikų manipuliavimas kariais. Jo nuomone, ịvairiais laikotarpiais, ịvairiose valstybėse politikai naudodavo kariuomenę kaip pretekstą vidaus politikos rietenoms: parlamentas prieš Karūną (D. Britanija), socialistai prieš konservatorius (Prancūzija ir Vokietija), kongresas prieš prezidentą (JAV). Tokią būklę jis pavadino subjektyvia civiline kontrole. ${ }^{7}$ Smetonos laikų Lietuva yra labai geras tokios būklès pavyzdys. ${ }^{8}$ Esant tokiai kontrolei kariuomenè po truputi ima politikuoti ir vis mažiau laiko skiria pagrindiniam savo darbui - rengtis karinėmis priemonėmis vykdyti duotas užduotis. Kuo daugiau kariuomenė isitraukia ị politiką, tuo prasčiau ji yra pasirengusi kautis.

Kad būtu galima išvengti tokios būklès, jis siūlo taikyti objektyvios kontrolès principą. Pasak jo, objektyvi civilių kontrolè „savo tikslą pasiekia militarizuodama kariuomenę, padarydama ją valstybės įrankiu“.9 Remdamasis Clausewitzo idejjų interpretacija jis siūlo labai aiškiai atskirti politinę ir karinę erdves ir suteikti joms autonomiją. Tai reiškia, kad politikai dirba ir veikia savo erdvejje, formuluoja kariuomenei užduotis ir kariškiai nesikiša i šs̆ procesą. Žvelgiant iš tokios perspektyvos, prieš tai aptarta britų premjero Camerono pozicija ir griežtumas yra geriau suprantamas.

Tačiau nuo tos akimirkos, kai politikai perduoda užduotis kariuomenei, jie neturi teisès kištis ir aiškinti karininkams, kaip vykdyti karines operacijas. Šiuo atveju tai karininkų veiklos sritis ir jie geriau išmano, ką ir kaip reikia daryti. Šią savo idejją Huntingtonas bande pagrịsti plačia istorine analize. Ypatingą dèmesị jis skyrè Vokietijos atvejui aptarti. Tam tikra prasme jis mané, kad jo siūloma objektyvios kontrolès idèja yra Vokietijos Generalinio štabo vado Moltkès išsakyto principo, kad „politikai turi nutilti iki tol, kol generolai pasieks pergalę ${ }^{\text {“10 }}$, pratęsimas. O per Moltkę Huntingtonas susieja savo teoriją su Clausewitzo tradicija, nes juk kaip tik Moltkès dèka jis ir tampa autoritetu karybos srityje. ${ }^{11}$

Taigi Huntingtono patarimas politikos praktikams buvo aiškiai atskirti politikos ir karybos sritis. Reakcijos ir kritikos labai ilgai laukti nereikejo. Aiškiausią ir pagrịstą kritiką pateikè kitas to meto JAV socialinių mokslų grandas, sociologas Janowtizas. Jis sutiko, kad situacija JAV vidaus politikoje po II pasaulinio karo tikrai kokybiškai nauja dèl taikos meto kariuomenès. Jis taip pat pritarè, jog būtina atrasti būdus karines pajègas kontroliuoti civiliams. Tačiau

\footnotetext{
${ }^{7}$ Ibid., pp. 81-82.

${ }^{8}$ Vaičenonis J., Lietuvos kariuomenè valstybès politinio gyvenimo verpetuose (1927-1940). Kaunas: Versus aureus, 2004.

${ }^{9}$ Huntington S. P., The Soldier and the State, p. 83.

${ }^{10}$ Ritter G., The Sword and the Sceptre: The Problem of Militarism in Germany (London: Allen Lane, The Penguin Press, 1972), Vol 4, p. 181.

${ }^{11}$ Paret P., Craig G. A., Gilbert F., Makers of Modern Strategy : From Machiavelli to the Nuclear Age (Oxford: Clarendon Press, 1986), pp. 281-295.
} 
jis pateikè visiškai kitoki „receptų“ sąrašą nei Huntingtonas. Anot Janowitzo, siūloma skirtis tarp politinès ir karinès sričių yra neįmanomas dalykas, ypač branduolinio ginklo laikais. ${ }^{12}$ Karinès pajègos dèl technologinių pokyčiu ir elementaraus fizinio dydžio pavirto ị labai sudètingą organizaciją, kurią valdyti reikia vadybinių, organizacinių igūdžių. Dar daugiau, visi šie igūdžiai nereikalauja specifinių karinių žinių ir gali būti perimti iš civilių. Kitais žodžiais tariant, didžioji dalis tų ir šių dienų karininkų yra niekas kita, kaip vadybininkai, vilkintys uniformas. ${ }^{13}$ Todèl geriausias būdas prižiūrèti kariškius yra jų neatskirti autonomineje erdvèje, o integruoti su civiliais, ịtraukti ị bendras darbo komandas. Dirbdami civiliškesneje aplinkoje kariškiai perims civilių, politines (pilietines) normas ir vertybes. Tokiu būdu kariškiai bus kontroliuojami civilių.

Dar daugiau, Janowitzas atkreipe dėmesị $\mathfrak{i}$ kintantị konfliktų pobūdị. Dekolonizacijos metu prasidejję konfliktai Afrikoje, Azijoje, Lotynų Amerikoje buvo visai kitokie kariniai konfliktai negu tie, kuriems ruošèsi NATO pajegos. Tačiau Vakarų valstybės viena ar kita forma neišvengiamai juose dalyvaudavo. Šie konfliktai reikalavo labiau „policinio“ (angl. constabulary) pobūdžio karinių pajègų, kurios paprastai reikalauja iš kariškių ne tik karinių, bet ir politinių, ekonominių, teisinių žinių. ${ }^{14}$ Vèlgi kintantis grèsmių ir konfliktų pobūdis reikalauja didesnio politinių ir karinių sričių integravimo, o ne atskyrimo.

Šios priešingos teorijos tapo vakarietiškų civilių ir kariškių santykių modelių pagrindu. Nors jie abu buvo kurti JAV poreikiams, Vašingtonas labiau institucionalizavo Huntingtono modeli, o Janowitzo modelis labiausiai tinka paaiškinti Jungtinès Karalystės sistemą, nors iš tiesų daugelyje Vakarų valstybių funkcionuoja mišrus modelis, tarp jų ir Lietuvoje. ${ }^{15}$

Šie du modeliai tapo visų po to sekusių revizijų, naujų civilių ir kariškių santykių interpretacijų pagrindu. Moskoso profesijos ir institucijos ${ }^{16}$, Descho

\footnotetext{
${ }^{12}$ Janowitz M., The Professional Soldier: a social and political portrait. New York: Free Press, 1960.

${ }^{13}$ Ibid, p. 36.

${ }^{14}$ Ibid, p. 320.

${ }^{15}$ Egnell R., "Explaining US and British Performance in Complex Expeditionary Operations", Journal of Strategic Studies, Vol. 29, Is. 6, 2006, pp. 1041-1075; Egnell R, Complex Peace Operations and Civil-Military Relations. London: Routledge, 2009.

${ }^{16}$ Moskos C. C., "From Institution to Occupation Trends in Military Organization," Armed Forces \& Society 4, No. 1 (October 1, 1977), pp. 41-50.the military organizations demonstrated key norms and values transcending self-interest, i.e. service. After the dissolution of the draft and the construction of the all-volunteer force, these institutional features seem to be evolving towards occupational policies, which use self-interest as motivational tools. Thus, for example, recruitment efforts under the all-volunteer force emphasize pay and benefits and deemphasize traditional military values. Given likely further development in the direction of the occupational model, two potential consequences are noted: the potential for trade unionism and the increased use of civilian technicians (contractors).
} 
išorinio veiksnio ${ }^{17}$, Feaverio patikètojo ir patikètinio ${ }^{18}$, Schiff sutikimo ${ }^{19}$, Avant institucinès raidos ${ }^{20}$, Feaverio ir Kohno atotrūkio ${ }^{21}$ modeliai yra atnaujintos, perdarytos Huntingtono ir Janowitzo pasiūlytų modelių versijos. Bendras visų šių teorijų ir modelių bruožas yra siekis sustiprinti civilių kontrolę ir neleisti kariškiams perimti valstybès valdymo. Kitais žodžiais tariant, visų šiu idèjų tikslas yra sukurti tokį institucinį mechanizmą, kuris neleistų kilti kariniam perversmui. Niekas negalètų prieštarauti tokiam siekiui, tačiau būtina pastebèti, kad šis modelis turi labai rimtų spragų, nes negali paaiškinti kitų formų ir būdų, kuriais kariškiai gali daryti poveikị civiliams. Esminè kritinè pastaba dèl šių modelių yra ta, kad jie visi remiasi labiau ontologinius (institucinius) aspektus iškeliančia galios samprata, kuri parodo ir aprèpia tik dalị vykstančių procesų.

Anot Jameso Burko, norint suprasti civilių ir kariškių santykius, siūlomų modelių variacijas ir iš to kylančias praktikas būtina suprasti, apie kokią demokratijos sampratą mes kalbame. Nuo to, kaip mes apsibrěšime demokratiją priklausys mūsų požiūris ị karines pajègas. ${ }^{22}$ Šiuo atveju norisi pasinaudoti puikiu Burko patarimu išskirti vieną pagrindinị elementą, leisiantị geriau suprasti civilių ir kariškių santykių raidą. Tik priešingai, nei jis siūlo, šiame straipsnyje pagrindiniu žodžiu yra ne demokratija, o galia (angl. power). Nuo to, kaip apibrèšime tai, kas yra galia, kokiomis formomis ji pasireiškia priklausys mūsų civilių ir kariškių sąveikos supratimas.

Britų sociologas M. Mannas yra pasiūlęs dviejų, vienu metu koegzistuojančių galios tipų idẻją. Vieną galios tipą jis pavadino despotine galia, o antraji infrastruktūrine galia. Pirmoji galios samprata atspindi „veiksmų, kuriuos elitas yra ịgalintas iggyendinti be nuolatinių institucionalizuotų derybų su pilietinès

\footnotetext{
${ }^{17}$ Desch M., Civilian Control of the Military. Baltimore: The Johns Hopkins University Press, 1999.

${ }^{18}$ Feaver P. D., Armed Servants: agency, oversight, and civil-military relations. Cambridge, Mass ; London: Harvard University Press, 2003.

19 Schiff R. L., "Concordance Theory: A Response to Recent Criticism," Armed Forces \& Society 23, No. 2 (January 1, 1996), pp 277-83.

${ }^{20}$ Avant D., Political Institutions and Military Change. Ithaca: Cornell University Press, 1994.

${ }^{21}$ Feaver P. D., Kohn R. H., Soldiers and Civilians the Civil-Military Gap and American National Security.

${ }^{22}$ Burk J., "Theories of Democratic Civil-Military Relations"showing how the classic and still influential theories of Huntington and Janowitz were rooted, respectively, in liberal and civic republican theories of democracy and, as a result, neither adequately solved this problem. The article then uses current research to pose new questions about the relations between military and political elites, the relations of civilians to the military and the state, and the multinational use of force. Based on the review, it concludes that a new theory of civil-military relations-one that accounts for the circumstances mature democracies presently face and tells how militaries can sustain as they protect democratic values cannot be derived from either liberal or civic republican models of democracy, as Huntington and Janowitz tried to do, but might be derived from federalist models.','author":[\{“family":"Burk,"'given”:”James”\}],"issued”:\{“date-parts”:[[“2002” ]],"season":"Fall"'\}\}\}],"schema":"https://github.com/citation-style-language/schema/raw/master/csl-citation. json"\} , Armed Forces \& Society. Fall 2002 vol. 29 no. 1, pp. 7-29
} 
visuomenės grupèmis, aprèptị. ${ }^{23}$ Tai yra iš viršaus, iš centro kylanti galia. Paprastai tariant, despotine galia koncentruojasi $\underset{i}{i}$ tą, kuris priima sprendimus.

Galima būtų teigti, kad Huntingtono, Janowitzo ir jų auklètinių modeliai kalba apie despotinès galios aspektus. Kaip minèta, šie modeliai siūlo ịvairius būdus, kaip neleisti kariuomenès atstovams perimti politinès sistemos centro kontrolès, t. y. perimti despotinès galios kontrolès.

Svarbu ir Lietuvos atvejo analizei tai, kad visi pagrindiniai karo sociologijos srities atstovai koncentravosi $\mathfrak{i}$ despotinès galios aspektus, nèra atsitiktinumas ir deviacija. Iš tiesų tai atspindys temų ir požiūrių, kurie vyrauja socialiniuose moksluose. Svarbu, kad Mannas savo pasiūlytas galios sampratas aiškina ir tiria valstybès kontekste, t. y. jo pagrindine sąvoka yra valstybė. Šiuo atveju reikia kalbèti apie valstybès sampratos interpretacijas ir jų kaitą. Itin svarbu suvokti, kaip valstybę supranta JAV akademinis elitas. Pastarojo kuriamos koncepcijos neginčijamai dominuoja ir diktuoja socialinių mokslų žaidimo taisykles. ${ }^{24}$

Ilgą laiką JAV buvo laikomasi nuomonès, kad tradicinè jos valstybės nevalstybiškumo (angl. statelessness) samprata darė poveikị socialinių mokslų raidai Amerikoje. ${ }^{25}$ Ištisos amerikiečių kartos manė, kad jos gyvena valstybèje, apie kurią XIX a. I pusėje A. de Tocqueville rašè, kad „niekas taip nestebina keliautojo iš Europos kaip nebuvimas to, ką mes vadiname vyriausybe arba administracija ${ }^{\text {"26 }}$. Todèl net ir šiais laikais mokslininkai kalba apie tai, kad JAV yra silpnos, tačiau turi labai stiprią pilietinę visuomenę. Todèl bet koks centrinès valdžios didejjimas, centrinio aparato plètimasis yra vertinamas labai ịtariai. $\mathrm{O}$ itarimą itin kelia karinių pajègų funkcionavimas, nes, kaip jau buvo minèta, nepasitikejjimas nuolatine reguliariąja kariuomene Amerikoje tęsiasi šimtmečius.

Tačiau per keletą pastarųjų dešimtmečių mokslininkai, tiriantys JAV valstybės institucijų raidą ir istoriją vis garsiau kalba apie tai, kad atėjo metas iš naujo įvertinti JAV valstybingumo klausimą. Naujausių mokslinių tyrimų rezultatai rodo, kad JAV valstybè buvo labiau intervenciné, stipresnè ir kontroliuojanti, nei mes norime tiketi. ${ }^{27}$

\footnotetext{
${ }^{23}$ Mann M., States, War and Capitalism : Studies in Political Sociology (Oxford: Basil Blackwell, 1988), p. 5. ${ }^{24}$ Backhouse R. E., Fontaine P., A Historiography of the Modern Social Sciences. New York : Cambridge University Press, 2014; Backhouse R. E., Fontaine P., The History of the Social Sciences since 1945. Cambridge : Cambridge University Press.

${ }^{25}$ Nettl J. P., “The State as a Conceptual Variable”, World Politics. Vol. 20, No. 4 (Jul., 1968), pp. 559-592.

${ }^{26}$ Tocqueville A., Apie Demokratija Amerikoje. Vilnius : Amžius, 1996, pp. 80-81.

${ }^{27}$ Novak W. J., 'The Myth of the "Weak" American State', American Historical Review, 2008, p. 756. Baldwin P., 'Beyond Weak and Strong: Rethinking the State in Comparative Policy History', Journal of Policy History, 17, 2005, pp. 12-33; King D. S, Lieberman R. C., 'Ironies of State Building: A Comparative Perspective on the American State', 2009, pp. 547-548; Novak; Orren K., Skowronek S., The Search for American Political Development (Cambridge, UK ; New York: Cambridge University Press, 2004).
} 
Tokiame kontekste M. Manno pasiūlyta dviejų koegzistuojančių galių ideja tampa svarbi šiems mokslininkams:

JAV valstybė (kaip ir jos revoliucija) yra sutelkta prieš despotinę galią. Ji yra apsėsta idejų apie valdžių atskyrimą, atsvarų sistemos sukūrimą: federacinis vs. valstijų vs. vietinis; vykdomoji vs. leidžiamoji vs. teisinè [...]. ${ }^{28}$

Citatoje pateiktą priešybių sąrašą būtų galima labai lengvai papildyti dar vienu: civiliai prieš kariškius. Ši skirtis labai gražiai papildo tradicinị JAV socialinių mokslų modelį. Taigi dominuojantys Vakaruose civilių ir kariškių modeliai buvo sukurti JAV valstybei remiantis Amerikietiška tradicija ir socialinių mokslų idejomis ir todèl juose dominuoja siekis ịvesti kontrolę, užtikrinti balansą. Tačiau toks požiūris kelia rimtų svarbių klausimų, ypač jeigu pažvelgtumėme ị civilių ir kariškių santykius iš kitos perspektyvos ir pasiremtumėme infrastruktūrinès galios samprata.

Infrastruktūros samprata yra „valstybės gebėjimas įsiskverbti $\mathfrak{i}$ visuomenès erdvę ir igyvendinti politinius sprendimus visoje politinèje erdveje..$^{29}$ Kitaip tariant šios galios samprata leidžia ieškoti atsakymų i klausimą: kaip yra igyvendinami sprendimai. Tokios galios apraiškas realiame gyvenime liudija tokie reiškiniai kaip raštingumas, mokesčiu sistemos, paštas, matų standartizacija, policijos patruliavimas. Kariuomenès srityje valstybės infrastruktūrinẻ galia pasireiškia biurokratizacijos, profesionalizacijos ir šauktinių kariuomenès formomis. ${ }^{30}$ Tai reiškia, kad civilių kontrolè yra užtikrinama per šias institucijas. Dar daugiau, siekiant panaudoti šią galios formą ir tokią kontrolę neužtenka vien tik institucijų. Tam reikia ir idejų socializacijos. Būtina, kad visuomenè ir kariuomenè priimtų šias institucijas ir funkcijas, laikytų jas legitimiomis. Kitaip tariant, galia ateina ir per diskurso ir žinojimo kontrolę. ${ }^{31}$ Tačiau Mannas aiškiai pabrèžè, kad infrastruktūrinè galia veikia kaip dvipusis eismas. Per tas pačias institucijas, per kurias valstybė veikia visuomenę ir atskirus jos segmentus, visuomenė gali veikti ir valstybę. Vadinasi kariuomenė gali veikti civilinę erdvę pasitelkusi biurokratinę sistemą, ar siūlydama savo diskursą.

Apibendrinant šią dalị būtų galima konstatuoti, kad Vakaruose dominuojantys civilių ir kariškių modeliai labiau pabrèžia politinio centro apsaugą nuo karinio elemento įtakos. Iš esmès pagal šiuos modelius ị visą šia situaciją žiūrima iš despotinès galios perspektyvos, koncentruojantis ties tuo, kas pri-

\footnotetext{
${ }^{28}$ Novak, p. 763.

${ }^{29}$ Mann M., States, War and Capitalism, p. 5.

${ }^{30}$ Mann M., The Sources of Social Power, ol. 2. Cambridge: Cambridge University Press, 1993, pp. 419-425.

${ }^{31}$ Infrastruktūrinès galios samprata turi aiškias sąsajas su M. Foucault'o idejomis apie galią, žinojimą ir galios socializaciją.
} 
ima sprendimus. Tačiau tai reiškia, kad šiuo metu vyraujantis žiūros taškas i civilių ir kariškių santykius aprépia ne visą vaizdą, o tai lemia, kad tam tikros veiklos nèra skatinamos arba neutralizuojamos. Kaip tik taip atsitiko su intelektualinès refleksijos klausimu ir svarba kariniuose reikaluose. Jos svarbą geriausiai galima parodyti apžvelgiant Clausewitzo idejjas.

\section{Clausewitzo idèjų revizija}

Pažvelgus ị ilgą Clausewitzo teksto interpretacijos ir pritaikymo istoriją galima aiškiai matyti, jog skirtingos kartos skirtingai interpretavo šio mąstytojo idejas. ${ }^{32}$ Nesutarimai ir didžiuliai debatai prasideda tada, kai pabandoma išsiaiškinti, kurie iš jo pabrèžtų elementų yra svarbesni ir daugiau lemia už kitus. Geriausiai šią ịtampą iliustruoja jo pateikti du karo apibrěżimai. Pirmasis skamba taip: „Karas yra jegos panaudojimo aktas siekiant priešą priversti paklusti mūsų valiai““. ${ }^{33} \mathrm{O}$ antrasis „karas yra politikos tęstinumas, tik vykdomas kitomis priemonèmis“. ${ }^{34}$ Atidžiai perskaitę ir ịsigilinę ị šių dviejų apibrèžimų formuluotes, matome esminių skirtumų ir prieštaravimų. Pirmajame labai pabrèžiamas valios elementas. Karas iš tiesų yra valių kova, kuri nebūtinai turi vykti mūšio lauke. Antrajame apibrèžime labai aiškiai pabrèžiamas politikos vaidmuo. Tai politika, kuri kaip praktika yra pastovi, tačiau nuolat kintantis jos turinys iš tiesų vis kitaip riboja karą ir todèl kiekvienoje epochoje kariaujama vis kitokiu būdu.

Būtina pabrèžti, kad antrasis apibrèžimas yra dažniausiai cituojama Clausewitzo knygos vieta ir taip pat raktas ị visą jo veikalo interpretaciją. Čia svarbu paminèti kai kuriuos šios knygos rašymo istorijos momentus. Visiems yra žinoma, kad prūsų generolas buvo pradejęs perrašinèti savo knygą. Tačiau nẻra aišku, ar jis perrašymo procesą pradejjo baigęs rašyti knygą. $M$. Howardo ir P. Pareto angliškame vertime teigiama, kad Clausewitzas pradejjo perrašinèti knygą ją baigęs ir iki mirties suspèjo perrašyti pirmosios knygos pirmajji skyrių. Pagal šią interpretaciją yra laikomasi pozicijos, kad pirmajame skyriuje surašytos mintys ir idejjos buvo labiausiai apgalvotos ir pasvertos, todèl vertos išskirtinio dèmesio, palyginti su likusia knyga. O šiame pirmajame skyriuje iš tiesų didžiulis dėmesys yra skiriamas politikai, kaip karą stabdančiam veiks-

\footnotetext{
${ }^{32}$ Strachan H., Herberg-Rothe A., Clausewitz in the Twenty-First Century (Oxford: Oxford University Press, 2009, pp. 14-44.

${ }^{33}$ Carl von Clausewitz, ed.a nd transl. by Howard M., Paret P., On War. Princeton: Princeton Univ. Press, 1989, p. 13.

${ }^{34}$ Ibid., p. 28.
} 
niui, aptarti. Ši pozicija pritaikoma paprastai politikai nustato užduotis, kariuomene igyvendina. Šiuo atveju politika kontroliuoja karinị veiksnị. O tai yra šių dienų pradinè civilių ir kariškių santykių pozicija.

Šią interpretaciją galima kritikuoti dèl dviejų dalykų. Pirmiausia Clausewitzas neišskiria tik politikos veiksnio. Ją jis mato kaip sudètinę nepaprastosios trejybès dalị. Realybeje karas skirtingais laikotarpiais igyja skirtingas formas ir jo brutali prigimtis yra ribojama trijų veiksnių (politikos, likimo ir emocijų), kuriuos jis pavadina nepaprastaja trejybe (angl. remarkable trinity). ${ }^{35}$ Šie trys veiksniai visada veikia ir riboja karą vienais kartais jis vyksta minimaliai praliejant kraują, o kai kuriais atvejais jis tampa beveik absoliutus. $\mathrm{O}$ visa tai apibendrinti galime šiais Clausewitzo išskirtais, universaliais principais: karo prigimtis yra brutalus kraujo praliejimas, kuris nuolatos ribojamas politikos, likimo, žmogaus aistrų ir instinktų. Šiuo atveju nèra jokių konkrečių instrukcijų, kaip laimèti mūšs. Tai labiau bandymas geriau suprati, kas yra karas. Iš to kyla natūralus klausimas kodèl Howardas ir Paretas versdami prūsų generolo knygą akcentavo tik politiką?

Dèl antrojo dalyko kritikuojama dar labiau. Liberalioje, instrumentinèje Clausewitzo karo sampratos interpretacijoje pradingsta interakcijos momentas. Kur visoje šioje istorijoje oponentas? Jis aptinkamas pirmajame karo apibrěžime, kuriuo akcentuojama ne politika, bet valia. Šiuo atveju valios primetimas savo oponentui pasako tai, kad priešininkas taip pat yra mąstantis, valingas subjektas. Todèl kai susiduria du valingi asmenys, pradinis puolimo ar gynybos planas, pasak Moltkès, „neatlaiko pirmojo susidūrimo su priešu“. ${ }^{36}$ Kuo ilgiau trunka ši kova, tuo karas ilgesnis ir autonomiškesnis. Karo metu dinamiškai vykstantys procesai pradeda diktuoti sąlygas ir keisti politinius tikslus. Todèl Clausewitzas ir teigè, kad gynyba yra stipresnè karo forma. Peršasi išvada, kad ta pusė, kuri greičiau prisitaikys prie naujų kovos sąlygų ir sąveikaudama su oponentu ras efektyvų būdą ịveikti oponento valią, pasieks pergalę. Tokio prisitaikymo neimmanoma pasiekti, jeigu karinès pajègos nepajègia konceptualiai reflektuoti.

Kitaip perskaičius Clausewitzą galima teigti, kad iš tiesų jis kalba apie civilių ir kariškių dialogą, o ne monologą. ${ }^{37} \mathrm{O}$ šio dialogo paskirtis yra labai paprasta - sukurti gerą ir efektyvią strategiją. Strategija yra ta jungtis, kuri jungia politinius tikslus su karinėmis priemonèmis. Norint, kad šie du elementai būtų suderinti, reikia gerai parengtos strategijos, kurios neimmanoma sukurti, jeigu

\footnotetext{
${ }^{35}$ Ibid., p. 30.

${ }^{36}$ Hughes D. J., Moltke on the Art of War: Selected Writings (Novato, CA: Presidio Press, 1995), p. 45.

${ }^{37}$ Strachan H., The Direction of War, p. 30.
} 
nèra konstruktyvaus civilių ir kariškių dialogo. Čia verta prisiminti Feaverio žodžius apie civilių dilemą. Žmonès bijo kariuomenès, kurią sukūrè gynybos sumetimais. Taigi gynybos elementas eina pirmiau už kariuomenès ribojimą. Tai reiškia, kad pirmiausia mes turime koncentruotis ị tai, ar mūsų karinés pajègos yra pasirengusios atlikti karines operacijas, o tam būtinas konstruktyvus civilių ir kariškių dialogas. Todèl galima sakyti, kad konstruktyvių civilių ir kariškių santykių esmè yra ne kariškių vadovavimas civiliams. Šių santykių tikslas yra strategijos kūrimas. O geros strategijos negalima suformuluoti, jeigu nèra supratimo, kokia sudetinga yra karo prigimtis. Tai itin sunku suvokti karinès patirties neturintiems civiliams. Karo prigimtis nèra ribojama tik politikos, ją riboja ir likimas, ir žmogiškosios emocijos. O visų šių trijų elementų konfigūracija skirtingais istoriniais momentais susidèlioja skirtingai. Todèl kariai, geriau suvokdami paskutinių dviejų veiksnių poveikį, gali aiškiau paaiškinti tai civiliams. Civiliai, išmanydami politikos subtilybes, gali paaiškinti kariams, kaip ir kodèl ji riboja karinių pajègų veiklą. Viso šito civiliai ir kariškiai nesupras, jeigu nesistengs nuolat kalbèti apie karo prigimtị ir jo pobūdžio kaitą. Kitaip tariant, diskusijos ir kritiška refleksija yra civilių ir kariškių santykių esmè. Tačiau norint ịvertinti šių diskusijų kokybę mums reikia kitokios prieigos, kitokio žiūros taško, kurių dominuojantys civilių ir kariškių santykių modeliai negali pasiūlyti. Šios teorijos leidžia įvertinti institucinius aspektus, tačiau šiuo atveju institucijos yra antrinis dalykas. Tikrąą galią turi ne tie, kurie užima atitinkamus postus, o tie, kurie kuria diskursus, naratyvus, koncepcijas. Juk be šių dalykų neįmanoma sukurti geros strategijos.

Senosios prieigos ribotumą labai gerai iliustruoja Feaverio pasiūlyta patikètojo ir patikètinio (angl. principal - agent) teorija. Joje civilių ir kariškių santykiai yra matomi kaip „strateginès interakcijos žaidimas“. ${ }^{38}$ Šio žaidimo metu civiliai nusprendžia, kokiu būdu geriausia stebèti kariškių veiksmus. O karinès pajègos, ịvertinusios stebėsenos institucijų stiprumą, efektyvumą ir gebejjimą bausti už netinkamus sprendimus, gali pasirinkti paklusimo arba išsisukinèjimo (angl. shirking) strategijas. Krizè kils tada, kai civiliai norès atlikti agresyvią stebėseną, o kariškiai norès išsisukti. ${ }^{39}$ Viena svarbiausių stebėsenos formų yra žiniasklaidos ir civilių ekspertų veikla. Tačiau tai yra būtina, bet nepakankama sąlyga. Kokia nauda iš stebėsenos, jeigu nesame pajègūs užduoti konceptualių klausimų apie kariuomenès siūlomą konceptualinę „produkciją“? Šiuo atveju vien tik institucinès kontrolès neužtenka, būtina ir turinio kontrolè.

\footnotetext{
${ }^{38}$ Feaver P. D., "Crisis as Shirking: An Agency Theory Explanation of the Souring of American Civil-Military Relations," Armed Forces \& Society 24, No. 3 (April 1, 1998), p. 407.

${ }^{39}$ Ibid., p. 448.
} 
Visa tai pamatyti ir ịvertinti leidžia infrastruktūrinès galios perspektyva ir su ja susijęs kontrolès užtikrinimas per ịvairių diskursų kūrimą. Žinojimas yra galia ir tie, kurie suteikia žinių, diktuoja sąlygas ir kontroliuoja visą procesą ${ }^{40}$ Paprastai tariant, jeigu karinių koncepcijų, teorijų kūrẻja yra tik kariuomenè, tai civiliai mokys apie karą pro jos pasiūlytus diskurso „akinius“. Dar daugiau, kariuomenè ir jai prielankūs ekspertai, gali diskusiją pasukti link techninio pobūdžio klausimų, o ne politinių, kuriuose jie tikrai turi viršenybę. Šiuo atveju vietoj klausimo, kodèl mes kažką darome su karinėmis pajègomis, pirmiau keliamas klausimas, su kokiomis priemonemis kariausim. ${ }^{41}$ Geras to pavyzdys galètų būti Lietuvoje vykstanti diskusija dẻl karinių šarvuočių ỉsigijimo. Visa diskusija yra ịgavusi gana stiprų techninį pobūdị, kuriame yra kalbama apie važiuoklę, šarvo storị ir t. t. O diskusijos apie tai, kokią funkciją atliks ši karinè technika igyvendinat strateginius tikslus, kokie doktrininiai sprendimai yra reikalingi, faktiškai nevyksta.

Taigi, tinkamos ir efektyvios strategijos neturèsime, jeigu neskatinsime civilių ir kariškių dialogo. Šiuo atveju mes turime kalbèti apie dviejų lygių refleksiją. Pirmiausia pačioje kariuomenëje turi būti išmokta atvirai diskutuoti ir keistis idèjomis apie karą, karybą. Išpildžius šią sąlygą žengiame ị kitą lygmenį, kuriame kariškių diskusijų metu gimusios idejos yra ịtraukiamos ị rimtesni pokalbị su civiliais. Šio pokalbio metu, viena vertus, yra užtikrinama diskursyvinẻ kariškių kontrolè ir sukuriama efektyvi strategija.

Svarbu, kad šis naujoviškas požiūris ị strategijos kūrimą ir sąsajas su civilių ir kariškių santykiais Vakaruose sulaukia pasipriešinimo, ypač dèl intelektualinio elemento svarbos. Pirmiausia visuomeneje egzistuoja stereotipinis i̊sivaizdavimas, kad karinių pajegu atstovai nepasižymi dideliais intelektualiniais gebẻjimais. Karinès pajègos, būdamos hierarchine, iš prigimties konservatyvia institucija, tikrai sunkiai priima naujoves.

Savo ruožtu karinès pajegos garsejja antiintelektualine tradicija. Skeptiškas požiūris ị kontempliatyvaus žmogaus vietą JAV, D. Britanijos, Prancūzijos ir kitų valstybių karinèse pajegose yra labai gerai dokumentuotas ir

\footnotetext{
${ }^{40}$ F. Lyotard, Postmodernus būvis. Vilnius : Baltos lankos, 1993.

${ }^{41}$ Dauber C., "The Practice of Argument: Reading the Condition of Civil-Military Relations," Armed Forces \& Society 24, No. 3 (April 1, 1998), p. 443.
} 
žinomas. ${ }^{42}$ Šios tradicijos atstovai laikosi nuostatos, kad karas yra tragiškas, žiaurus reiškinys, kurio vedimui, visų pirma, reikia labai daug praktinių igūdžių. Todèl kariuomenejje reikia ne kontempliatyvaus, bet veiklaus žmogaus. ${ }^{43}$ $\mathrm{O}$ tai reiškia, kad karinès pajėgos nèra vieta užsiimti intelektualine refleksija ir nèra linkusios toleruoti tai norinčius daryti karininkus. Turbūt radikaliausios pozicijos šiuo klausimu laikosi žinomas amerikiečių karo apžvalgininkas R. Petersas, teigdamas, kad „kariniame kontekste teorija yra žudikè, ji žudo aktyviai ir pasyviai“" ${ }^{44}$ Karineje praktikoje tokios pozicijos šalininkai iškelia D. Britanijos pavyzdį, kuri garsèja, ar bent jau garsëjo savo „išsikapanojimo“ (angl. muddling through) tradicija, kai kiekvienos operacijos metu yra taikomi pragmatiški ad hoc sprendimai ir mažiau paisoma doktrininių reikalavimų. ${ }^{45}$ Tačiau reikia pabrèžti, kad intelektualinè refleksija nèra tik knygų, straipsnių rašymas ar debatų ir konferencijų organizavimas. Tai yra daug platesnio pobūdžio veikla ir gebejjimai. Intelektualinis smalsumas yra būtina sąlyga bet kokiai inovatyviai veiklai. O kaip tik tokia veikla ir yra būdinga kariuomenei. Nuolat kintanti karyba, technologinès galimybès ir ypač politinès karų aplinkybės verčia kareivius ir jų vadus be paliovos prisitaikyti prie naujų sąlygų.

Todèl žvelgiant iš tokios perspektyvos karinè tarnyba yra prieštaringa. Viena vertus, geras kareivis vykdo jam duotą ịsakymą ir neužduoda daug klausimų. Tačiau kita vertus, poreikis prisitaikyti prie nuolat kintančių aplinkos sąlygų reikalauja gebejimų, kurie skatina užduoti klausimus, o pastarieji verčia galvoti ir reflektuoti. Kaip yra pastebejęs britų karo istorikas J. Keeganas, modernioje kariuomenejje rengiant karininkus iš pradžių reikia „,ǔdaryti jų protus sudètingoms idejjoms“, o vèliau iš naujo juos atverti „ne vienmačiam, $o$ daugiamačiam pasaulio matymui“ ${ }^{46}$

Apibendrinant visa tai, kas buvo pasakyta, būtų galima teigti, kad Vakaruose dominuojančios civilių ir kariškių teorijos vadovaujasi liberalia Clau-

\footnotetext{
${ }^{42}$ Snider D., Matthews L., The Future of the Army Profession, Revised and Expanded Second Edition, 2nd ed. (Learning Solutions, 2005); Reid B. H., "What Is Command Culture?," Journal of Strategic Studies 38, No. 1-2, January 2, 2015, pp. 215-31, doi:10.1080/01402390.2015.997547; Muth J., Command Culture: Officer Education in the U.S. Army and the German Armed Forces, 19011940, and the Consequences for World War II, 1st ed. (Denton, Tex: University of North Texas Press, 2011); Robert A. Doughty, The Seeds of Disaster: The Development of French Army Doctrine, 19191939 (Hamden, Conn: Archon Books, 1985); Paddy Griffith, Military Thought in the French Army, 1815-51, War, Armed Forces, and Society Y (Manchester: Manchester University Press, 1989); Correlli Barnett, “The Education of Military Elites," Journal of Contemporary History 2, No. 3 (July 1, 1967), pp. 15-35.

${ }^{43}$ Snider D., Matthews L., The Future of the Army Profession, Revised and Expanded Second Edition, p. 61.

${ }^{44}$ Peters R., "Learning to Lose," The American Interest, 2007, p. 25.

${ }^{45}$ King A., "Military Command in the Last Decade"; Egnell, "Explaining US and British Performance in Complex Expeditionary Operations."

${ }^{46}$ Keegan J., The Face of Battle. Harmondsworth: Penguin, 1978, pp. $22-23$.
} 
sewitzo idẻjų interpretacija, kuri pabrèžia politikos viršenybę karo atveju. Savo ruožtu liberali politinè tradicija akcentuoja valdžios paskirstymą, kad joks despotas nepajegtų užimti politinio centro ir itin ịtariai žiūrima ị kariuomenę. Ji yra matoma kaip būtinas blogis, kuris turi būti itin prižiūrimas ir kontroliuojamas. Tačiau visgi pirminè kariuomenès funkcija yra karyba ir todèl civilių ir kariškių santykiai turi sukurti sąlygas, kad karinių pajègų atstovai būtų pajègūs kurti karinius planus ir juos igyvendinti. Šiuo atveju institucinè-politinè kontrolè, nors ir yra labai svarbi, negali būti vienintelè kontrolès forma. Intelektualinès refleksijos svarba yra ne ką mažesnè, nes ji užtikrina tiek efektyvios strategijos parengimą, tiek leidžia vykdyti diskursyvią civilinę kontrolę.

\section{Civilių ir kariškių santykių raida Lietuvoje}

Baltijos valstybėms atkūrus nepriklausomybę, jų situacija buvo unikali. Jos kūrè savo karines sistemas faktiškai nuo nulio. Vieninteliai dalykai, kuriuos mes perèmėme iš sovietinių laikų, buvo karinès paskirties pastatai, infrastruktūra ir sovietinèje kariuomenejje tarnavę karininkai. Visa kita (ịstatymų bazę, institucijas, karinių pajègų struktūrą) teko kurti iš naujo remiantis vakarietiška patirtimi.

Demokratinès civilinės kariškių kontrolès užtikrinimas buvo būtina sąlyga norint ịsilieti ị Vakarų politinę bendruomenę. Šis procesas vyko dviem lygiais. Civiliai mate kariškių kontrolès mechanizmų stiprinimą kaip didesnès politinès transformacijos, perejjimo ị demokratiją, dalị. ${ }^{47} \mathrm{O}$ pamažu besiformuojantis ir stiprejjantis profesionalių karininkų sluoksnis pradejjo perimti tarptautines karines normas. Pasak Theo Farrello, naujai formuojamos karinès struktūros, ịsitraukdamos ị tarptautinę veiklą, perima dvi esmines normų grupes, kurios yra laikomos karinio profesionalumo pagrindu: konvencinès karybos normas ir civilių viršenybès ideją ${ }^{48}$ Kitaip tariant, jeigu Lietuvos kariuomenè norejjo būti pripažinta tarptautinio „karinio klubo“, ji privalëjo išmokti paklusti civiliams.

Šis išskyrimas ị dviejų lygmenų raidą yra svarbus ir dèl kitos priežasties. Jis parodo procesų eiliškumą. Šiuo atveju galima pritaikyti Thedos Skocpol idẻją, kad skirtingą Vakarų valstybių raidą nulėmé demokratizacijos ir biurokratizacijos

\footnotetext{
${ }^{47}$ O’Donnell G., Schmitter P. C., Transitions from Authoritarian Rule : Tentative Conclusions about Uncertain Democracies. Baltimore ; London: The JHopkins University Press, 1989.

${ }^{48}$ Farrell T., "Transnational Norms and Military Development: Constructing Ireland's Professional Army," European Journal of International Relations 7, No. 1 (March 1, 2001), pp. 73-75.
} 
procesų eiliškumas ir iš to plaukiančios konfigūracijos. ${ }^{49}$ Baltijos šalyse, priešingai nei kituose po sovietinėse valstybėse (Lenkijoje, Vengrijoje), pirmiau ịvyksta demokratizacija, o tik po to yra kuriama biurokratinè krašto apsaugos infrastruktūra. Taigi pas mus pirmiau ịsigali nuostata, kad civiliai turi kontroliuoti karius ir daryti tai demokratiškai, o tik po to galvojame, kaip tai realiai padaryti.

Civilinès kontrolès įdiegimas nebuvo lengvas uždavinys. Užtenka prisiminti 1993 m. liepą ì mišką pasitraukusių savanorių istoriją. Šis savanorių poelgis buvo didžiausia krizè civilių ir kariškių santykiuose, vèliau situacija gerejjo. ${ }^{50}$ Tačiau tai nereiškia, kad nebūta įtampos. Dalis karininkų nevengè viešai politikuoti. ${ }^{51}$ Pervertus to meto žurnalo Kardas numerius matyti, kad tarp pirmojo krašto apsaugos ministro A. Butkevičiaus ir ịvairių atsargos karininkų tvyrojo didele įtampa. ${ }^{52}$ Savo ruožtu nemažai ịtampos ir nesutarimų buvo tarp tarpukario atsargos karininkų, karininkų, kurie tarnybą pradejjo 1990-1991 m. ir tų, kurie buvo atlikę tarnybą sovietinëje kariuomenèje. Vèliau visą šią painią situaciją dar labiau komplikavo grịžę išeivijos karininkai. Apskritai, pirmajj dešimtmetị atmosfera karinių pajègų viduje ir tarp kariškių ir civilių buvo gana itempta. Kita vertus, tikètis brandžios veiklos ir diskusijų iš institucijų ir jas nuo nulio kuriančių žmonių, būtų naivu.

Iš tiesų $2000 \mathrm{~m}$. minint krašto apsaugos sistemos ịkūrimo 10-metị Lietuva turëjo teisiškai ir biurokratiškai funkcionuojančią civilių ir kariškių santykių sistemą. Nuo $1996 \mathrm{~m}$. buvo priimta daug įstatymų, kuriuose buvo aiškiai apibrèžtos visų institucijų ir pareigūnų veiklos ribos, kompetencijos: Nacionalinio saugumo pagrindų (1996 m.), Krašto apsaugos sistemos organizavimo ir karo tarnybos (1998 m.), Tarptautinių operacijų ir karinių pratybų (1998 m.), Karo prievolès (1999 m.), Ginkluotos gynybos ir pasipriešinimo agresijai

\footnotetext{
${ }^{49}$ Orloff A. Sh., Skocpol Th., "Why Not Equal Protection?"

${ }^{50} \mathrm{Kita}$ rimta krizè, bet tuo metu nutylèta ir nežinoma visuomenei buvo $2004 \mathrm{~m}$. pavasarị ịvykęs vadinamasis jègerių suokalbis. Jo metu, prieš pat Lietuvos narystès NATO pradžią ir JAV SOP planuotą įvertinimą, besiruošiančio trečiojo specialiujų operacijų eskadrono „Aitvaras 04 “ nariai iš jègerių bataliono (14 karių) ịteike raštiškus atsisakymus vykti ị Afganistaną. Susidariusi situacija buvo operatyviai ir tyliai išspręsta. Tačiau ji parode, kaip greitai situacija gali eskaluotis ir pasidaryti sunkiai kontroliuojama. Matonis A., Gabrieliaus kariai : Lietuvos specialiuju operaciju pajęgu ir Aitvaro istorija. Vilnius: Versus aureus, 2014, pp. 88-92.

${ }^{51}$ Urbelis V., Urbonas T., „The Challenges of Civil-Military Relations and Democratic Control of Armed Forces: the Case of Lithuania" kn. Andrew Cottey, Timothy Edmunds, and Anthony Forster, Democratic Control of the Military in Postcommunist Europe : Guarding the Guards, (Basingstoke: Palgrave, 2002, pp. 108-125).

${ }^{52}$ Pilkauskas Z., „Žuvis genda nuo galvos, arba apie kai kuriuos karvedžius“, Kardas, 1994 m., Nr. 34, p. 20-22; Česnulevičius V., „Dèl doc. Z. Pilkausko straipsnio „Žuvis genda nuo galvos, arba apie kai kuriuos karvedžius“, Kardas, 1994 m., Nr. 56, p. 46-47; „Dar kartą apie karvedžius“, Kardas, 1994 m., Nr. 78, p. 40; „Istorinè konferencija: Lietuvos kariuomenès atkūrimo ištakos ir problemos 1988-1990 m.., Kardas, 1998 m. Nr. 12, p. 20-26.
} 
(2000 m.) įstatymus; naujus Krašto apsaugos ministerijos nuostatus (1998 m.) ir kt. Galiausiai $2000 \mathrm{~m}$. buvo patvirtinta pirmoji Lietuvos karinès gynybos strategija, kurioje greta atgrasinimas, visuotine ir besąlygiška gynyba, euroatlantinis solidarumas ir kolektyvinè gynyba demokratinė civilinė ginkluotojų pajègų kontrolè yra fundamentalūs principai, ant kurių pastatyta visa valstybės karinio saugumo architektūra.

Šiuo atveju Lietuvoje buvo sukurta labiau Huntingtono principais paremta sistema, kurioje politinė ir karinė sritys buvo aiškiai atskirtos. Mechanizmas užtikrinti kad despotinę galią kontroliuotų civiliai buvo garantuotas. Pirmasis etapas - formalumų perèmimas, buvo ịvykdytas, liko kokybiškai užtikrinti antrąji - kasdienị perimtų principų, ịtvirtintų teisinių punktų igyvendinimą ir praktikavimą. Tai, kad sistemą reikejjo tobulinti ir tvarkyti, rode mokslininkų ir ekspertų publikacijos. ${ }^{53}$

Vakarų mokslininkai visus šiuos procesus ịvertino teigiamai. Jų teigimu, pokomunistinès valstybès sẻkmingai perėmè vakarietiškus teisinius, institucinius, biurokratinius civilių kontrolès mechanizmus. ${ }^{54}$ Kitaip tariant, buvo perimta forma, tačiau iki galo neaišku, ar buvo ir kaip buvo perimtas turinys. Cottey tai pavadino antrosios kartos problematika (angl. The Second Generation Problematic). Perèmus institucinę struktūrą, kitas žingsnis turètų būti kokybiško turinio užtikrinimas, t. y. gerai ir efektyviai funkcionuojantiems civilių ir kariškių santykiams neužtenka vien tik gerai surašytų ịstatymų, pareigingai dirbančių valstybės tarnautojų ir gerai parengtų karinių pajęgų. Būtina, kad apie visus šiuos dalykus: kodèl ir kaip turi funkcionuoti su krašto gynyba susiję istatymai, kodèl ir kaip karinès pajègos rengiamos, diskutuotų ir visuomenè. Paprastai tariant, geriems civilių ir kariškių santykiams būtina kokybiška refleksija apie karinius dalykus ir ị ši procesą būtinai turi ịsitraukti visuomené. ${ }^{55}$ Tačiau niekas nekvestionavo pačios sistemos principų ir jų ịtvirtinimo. Iš tiesų pačių publikacijų turinys ir ten pateikiamos rekomendacijos labai aiškiai parodo, kad svarbiausiu elementu civilių ir kariškių santykiuose išlieka institucinio valstybès galios centro apsauga. Galų gale mes labiausiai bijome ir saugomės kariškių itakos politiniam centrui.

Viena vertus, ị Vakarų mokslininkų pastebejjimą tikrai reikia atkreipti

\footnotetext{
${ }^{53}$ Cottey A., Edmunds T., Forster A., "The Second Generation Problematic: Rethinking Democracy and Civil-Military Relations," Armed Forces \& Society 29, No. 1 (October 1, 2002): pp. 31-56; Gricius A., Paulauskas K., Demokratiné civilinė ginkluotujų pajègų kontrolè Lietuvoje "Lietuvos metiné strateginé apžvalga 2002, 2003 m., p. 217-236; Urbelis ir Urbonas.

54 Cotey A., "The Second Generation Problematic: Rethinking Democracy and Civil-Military Relations," Armed Forces \& Society 29, No. 1 (2002): 31-56.

${ }^{55}$ Ibid.
} 
dèmesį, tačiau, kita vertus, reikia paminèti, kad mokslininkų išsakytos pastabos nèra teisingos pokomunistinèms valstybèms. Iš tiesų jų kritiką būtų galima nukreipti ir ị brandžias vakarietiškas demokratijas. Vakarų naudojamas ir mums pasiūlytas civilių ir kariškių santykių modelis dèl savo instrumentinès prigimties neleidžia iki galo išpildyti antro refleksijos etapo.

Nenumatyta neigiama viso šito pasekmé yra ta, kad toks procesų eiliškumas neleido išplètoti adekvačios institucinès struktūros, skirtos karinei refleksijai, o tai savo ruožtu trukdè tęsti atitinkamas tradicijas. Šiuo atveju yra svarbu pabrèžti prioritetų ir intensyvumo laipsnį. Tikrai nenorima pasakyti, kad nereikẻjo sukurti įstatymų bazès, kuri aiškiai apibrèžtų civilių ir kariškių pareigas, teises, darbų padalijimą, karinių pajègų struktūrą. Visa tai svarbu, tačiau civilių ir kariškių sąveika nesibaigia ties šiais dalykais.

Taip pat per didelis susikoncentravimas ị institucinę struktūrą neleido adekvačiai ịvertinti kitų vakarietiškų karinių tradicijų. Kita vertus, Lietuvos negalima per daug kaltinti. Mes klausėmès patarèjų ir konsultantų iš užsienio valstybių, perėmėme tai, kas buvo laikoma gerąa patirtimi.

Ši tarptautinių (vakarietiškų) praktikų, tradicijų, idejjų difuzija įneša tam tikros sumaišties. Tiesiog reikia pastebèti, kad kai Huntingtonas ir Janowitzas parengè savo modelius ir kalbejjo apie karininkijos profesionalizaciją, jie kaip savaime suprantamą dalyką prièmė egzistuojančią amerikiečių ir britų karinès edukacijos ir švietimo sistemą, kuri ir garantavo tam tikrą intelektualinės refleksijos lygi. Ši tradicija koegzistuoja su kiek anksčiau aptarta antiintelektualizmo tradicija Vakarų karinėse pajègose. Ş̣ koegzistavimą turbūt geriausiai iliustruoja karinès žiniasklaidos formatas. JAV karinių pajègų leidiniai Parameters, Military review, Joint Force Quarterly, Air and space power journall, Naval War College review; britu RUSI journal, British army review; rusų Военная Мысль ir t. t. Šiuose ir panašaus pobūdžio leidiniuose karininkai, civiliai ekspertai, mokslininkai, politikai dalijasi savo patirtimi, siūlo naujas koncepcijas, teorines inovacijas, pateikia naujausių karų ir konfliktų analizę. Šių leidinių puslapiuose gimé ne viena strateginio ir operacinio lygmens ideja, kurios laikui bėgant tapo karinès praktikos dalimi. Tokiuose leidiniuose normalu, jeigu majoras polemizuoja su pulkininku ar generolu. Tokia erdve tarnauja ne tik minčių keitimuisi, kuris gali nuvesti prie efektyvios strategijos sukūrimo. Diskusijos šioje erdvẻje taip pat leidžia matyti ir stebėti, koks diskursas, idèjos vyrauja kariškių gretose, o tai savo ruožtu leidžia geriau vykdyti civilinę karinio suvokimo kontrolę. Taigi būtų galima teigti, kad amerikiečių mokslininkų pasiūlyti modeliai buvo kuriami egzistuojant tam tikroms tradicijoms. Kai bent dalis karininkų savo šalyje yra igiję gerą karinị išsilavinimą ir nuolat užsiima 
savo veiklos refleksija, galima kur kas lengviau kalbèti apie politinès veiklos atskyrimą nuo karinès arba, atvirkščiai - apie didesnị šių dimensijų suliejimą. Todèl, kai kūrèsi Lietuvos krašto apsaugos sistema, remiantis Vakarų patirtimi, buvo mažiau akcentuojama karinio švietimo svarba, o tai atsiliepė intelektualinès refleksijos kokybei.

Jeigu užmestumėme akị ị lietuvišką praktiką, tai iš pirmo žvilgsnio atrodytų, kad ir mes turime savo karinès žiniasklaidos tradicijų. Krašto apsaugos sistema leidžia daug periodinių leidinių: Kardas, Karys, Kariūnas, Krašto apsauga. Jeigu vakarietišką praktiką laikysime tam tikru idealiuoju modeliu, tai lietuviškuose leidiniuose būtų galima tikètis rasti diskusijų apie karo teoriją, operacijų, kuriose dalyvauja šalies arba jos sąungininkų kariai, analizę, einamụjų reikalų apžvalgą. Tačiau verčiant šių žurnalų puslapius tenka nusvilti. Per 25 nepriklausomybès metus juose buvo publikuota mažai tekstų, kuriuose būtų kalbama apie karo teoriją, teorijos ir praktikos santykị. Dar didesnis iššūkis rasti straipsnių šia tema, parašytų ne civilių ir ne atsargos karininkų, o tarnybą atliekančių karininkų. ${ }^{56}$

Šiuo atveju norisi pabrèžti, kad kalbama apie publikacijas, kurios yra ne apie bataliono gyvenimą ar pratybas. Tokių publikacijų gausu ir jų autoriais dažniausiai būna karininkai. Tačiau rimtai ekspertų diskusijai reikia tekstų apie šalies deklaruojamus karybos principus ir formas: teritorinè gynyba ir jos variacijos, manevrinè karyba, karinè transformacija, kova mieste ir pan. Prie tokių publikacijų būtų galima priskirti plk. S. Knezio pirmojo Čečènijos karo eigos analizę ${ }^{57}$, plk. ltn. J. Užurkos ir jo kolegų idejjas apie nacionalinị saugumą ir teritorinę gynybą ${ }^{58}$, kpt. A. Alonderio mintis apie informacinę karybą ir karinę lyderystę ${ }^{59}$, mjr. A. Daugirdo taktinio lygmens kovų analizes ${ }^{60}$ ar kpt. I. Miškinio šiuolaikinių karinių praktikų ir koncepcijų

\footnotetext{
${ }^{56}$ Geriausias tokio atvejo pavyzdys gali būti dim. plk. doc. dr. Algimanto Vaitkaičio straipsniai apie karybos srities revoliuciją, naujausias karines technologijas ir Lietuvos gynybos politiką. Vaitkaitis A., „Ar mūsų kariuomenè apgins Lietuvą?“, Kardas, 2009 m., Nr. 1, p. 12-13; Vaitkaitis A., „Revoliucija karybos „srityje“, 2009 m., Kardas, Nr. 2, p. 16-19; Vaitkaitis A., „Ateities karams reikia kitokių ginkluotųjų pajègų, 2010 m., Kardas, Nr. 5, p. 25 ir Nr. 6, p. 18-21.

${ }^{57}$ Knezys S., „Keturi karo Čečènijoje etapai“, Karys, 1995 m., Nr. 3, pp. 16-18; Karys, 1995 m., Nr. 6, 16-19; „Nepaskelbtas karas Čečènijai arba čečènų karo pamoka Rusijai“, Kardas, 1995 m., Nr. 3-4, pp. 35-39.

${ }^{58}$ Užurka J., „Mūsų valstybès saugumo kriterijai“, Kardas, 1996 m., Nr. 34, pp. 8-9; Užurka J., Vaitkaitis F., Eidukaitis V., „Lietuvos valstybès teritorinès gynybos pagrindų metmenys“, Kardas, 2000 m., Nr. 3, pp. 6-11;

${ }^{59}$ Kanauka A. V., Alonderis A., „Informacija ir dezinformacija - nauji kovos būdai“, Kardas, 2002 m., Nr. 2, pp. 17-21; Alonderis A., „Pašaukimas - būti lyderiu“, Kardas, 2006 m., Nr. 2, pp. 24-31

${ }^{60}$ Daugirdas A., „Kova mieste. Lietuviška versija“, Karys, 2010 m., Nr. 1, pp. 12-17; Daugirdas A., „Kovinių veiksmų pavyzdžiai“, Karys, 2010 m. Nr. 2, pp. 42-46 ir Nr. 3. pp. 22-25; Daugirdas A., „Lietuvos partizanų taktikos ypatumai“, Karys, 2011 m., Nr. 5., pp. 32-35 ir Nr. 6, pp. 30-33.
} 
apžvalgas. ${ }^{61}$ Tačiau nepaisant įdomių, originalių ižvalgų, skaitant visus šiuos tekstus $\mathfrak{i}$ akis krenta vienas dalykas - nèra nei chronologinio, nei tematinio nuoseklumo, fragmentiška.

Kardo ir Kario numeriuose galima rasti daug straipsnių apie LDK karybos istoriją, Lietuvos nepriklausomybės kovas ir Lietuvos kariuomenės raidą, rezistenciją, jų dalyvių prisiminimus, apie įvairią ginkluotę ir karinę techniką. 1990-2000 m. laikotarpiui taip pat būdingas politinių ir asmeninių sąskaitų suvedinejjimas.

Tačiau publikacijų apie dabartinę Lietuvos karinę patirti yra mažai. Dažnai apsiribojama faktų išdèstymu, paviršutiniška analize, kurią būtų sunku pavadinti ekspertine. Žinoma, negalima sakyti, kad nẻra įdomių, dèmesio vertų publikacijų. Pvz., būtų galima išskirti Kardo žurnalo korespondento D. Sutkaus publikacijas, kuriose autorius bando supažindinti skaitytojus su naujesne karine kitų valstybių patirtimi. Tačiau būtina dar kartą pabrèžti, kad panašiomis temomis rašančių karininkų tikrai nedaug.

Visų šių diskusijų skurdumas išryškẻja, kai lyginame šių dienų situaciją su tarpukario Lietuvos. Tuo metu, greta Kardo ir Kario buvo leidžiamas dar vienas rimtas periodinis leidinys Mūsų žinynas. Šio leidinio straipsnių pavadinimai daug ką pasako: Stabdomujų kautyniu pagrindiniai désniai; Prancūzu ir vokiečiu péstininku karo doktrina; Taktikos idëju evoliucija vakaru fronte per didiji karą; Šarvuočiu puolimo galimumai sujungtu ginklų kautynese. İžangos žodyje teigiama, kad „Mūsų Žinynui rūpi iškelti Lietuvos armijos intelektą specialių karo mokslų ir bendrųjų mokslų iki tokio laipsnio, kokio yra pasiekusios kitų civilizuotų valstybių armijos".62 Kitais žodžiais tariant šis leidinys buvo skirtas diskusijoms ir aptarti karybos teoriją ir praktiką. Dar daugiau, didžioji dalis autorių buvo karininkai. Atsižvelgiant ị visa tai, kyla klausimas, kodèl atkūrus nepriklausomybę buvo atnaujinta Kardo ir Kario leidyba, o Mūsų žinyno - ne. ${ }^{63} \mathrm{Jau}$ vien tai pasako daug apie požiūrị $\mathfrak{i}$ karinę refleksiją ir apie jos kokybę.

Faktiškai vienintelis kartas, kai rimtesnių publikacijų ir diskusijų trūkumas buvo aiškiai ịvardytas, tai 1996 m. Kardo redakcijos baltosios pirštinès iššūkis „Kokie vadai - tokia ir kariuomenë“. Šia akcija buvo siekiama išprovokuoti karininkiją, kad ši pradètų aktyviau publikuoti, diskutuoti ir prenumeruoti karinès žiniasklaidos leidinius. ${ }^{64}$

\footnotetext{
${ }^{61}$ Miškinis I., „Terorizmas ir partizaninis karas šiandien“, Kardas, 2010 m., Nr. 4, pp. 26-29; Miškinis I., „Totalus ir lokalus karas“, Kardas, 2011 m., pp. 10-13.

${ }^{62}$ „Mūsų žinynas : karo mokslo ir literatūros žurnalas“ 1 T. (1921), p. 2.

${ }^{63}$ Straipsnio autoriui 2013-2014 m. bendraujant su Lietuvos kariuomenès vadais, Karo akademijos atstovais teko išgirsti, kad yra svarstoma pradèti vèl leisti Mūsų žinyną.

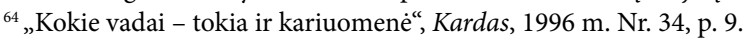


Aktyviausiai ị mestą iššūkị reagavo vyr. ltn. V. Voveris. Kalbėdamas apie leidinių temas jis teigè, kad „vyrauja prisiminimai, kurie kartojasi ir yra įdomūs tik pačiam autoriui ir jų artimiesiems". ${ }^{65}$ Anot jo, labiausiai karininkai laukia tekstų apie kariuomenès reikalus, karininkų tarnybą, karybos teoriją ir praktiką. Tačiau V. Voverio mintys apie atsiminimų kritiką sukèlè audringą reakciją, kuri neleido pradèti kokybiškos diskusijos apie einamuosius karinius reikalus. ${ }^{66}$

Apie karininkijos norą ir gebėjimą diskutuoti daug ką pasako Kardo puslapiuose aprašytos diskusijos apie karinę doktriną ${ }^{67}$ Vèlgi apie tai, kad Lietuvai būtina turèti savo karinę doktriną buvo kalbama nuo pat kariuomenès sukūrimo dienos, tačiau ją pavyko patvirtinti tik $2010 \mathrm{~m} .{ }^{68}$ Skaitant ịvairių karininkų ir civilių pasisakymus $\underset{\mathfrak{i}}{\mathrm{a}}$ akis krenta tai, kad niekas negali aiškiai pasakyti, kas yra karinė doktrina, kokia jos funkcija. Dažnai kartojama formuluotè, kad karinè doktrina turi plaukti iš Nacionalinio saugumo ir Lietuvos Respublikos karinès strategijos. Tačiau koks turètų būti jos turinys, kokie karybos principai turètų būti lietuviškos karybos pamatu? Apie visa tai nèra kalbama. Kaip pastebejo T. Jermalavičius, susidaro ịspūdis, kad „gal mąstome pernelyg siaurai ir žinybiškai“" 69

Doktrinos kūrimo istorija puikai iliustruoja karinès refleksijos būklę. Kuriant tokios svarbos dokumentą karinejje ir ekspertinejje periodikoje turejjo vyki rimtos diskusijos dèl doktrinų tipų, kitų valstybių patirties, karinių principų ir koncepcijų tinkamumo. Tačiau iš tiesų buvo apsiribota vos keliomis paviršutiniškomis publikacijomis. Pirmas rimtas mokslinis tekstas apie doktrinos supratimą Lietuvoje pasirodè tik $2014 \mathrm{~m} .{ }^{70}$ Galų gale turime situaciją, kai Lietuvos karinèje doktrinoje yra teigiama, kad „tikslinis vadovavimas (angl. mission command) yra pamatinis Lietuvos kariuomenės karybos principas“.71 Toliau doktrinoje yra teigiama, kad „tai lankstus, pragmatiškas ir decentra-

\footnotetext{
${ }^{65}$ Voveris V., „Klausimai be atsakymų“, Kardas, 1997 m., Nr. 12, p. 10.

${ }^{66}$ Navaitis A., „Atsakymai ị klausimus“, Kardas, 1997 m., Nr. 56, p. 26; Abraitis J., „Vertinime būtinas objektyvumas“, Kardas, 1997 m., Nr. 78, p. 27; Atutis A., „Eilutès iš laiško“, Kardas, 1997 m., Nr. 78, p. 27. ${ }^{67}$ „Ar Lietuvai reikia karinès doktrinos?“, Kardas, 2009 m., Nr. 5, p. 8-18.

${ }^{68}$ Jucys S., „Persų įlankos karo pamokos... Lietuvai“, Karys, 1993 m., Nr. 3, pp. 14-15; Žukas J. V., „Reguliarios kariuomenès ir teritorinès gynybos dalinių sąveikos problemos“, žr.: Teritoriné gynyba : (1995 m. saus. 25 d. seminaro medžiaga, Vilnius). Vilnius: Lietuvos karo akademija, 1995, p. 34-36; Lietuvos karine doktrina.

${ }^{69}$ Ibid., p. 13.

${ }^{70}$ Jokubauskas V., „Karine doktrina: Tarpukario Lietuvos kariuomenès atvejis (1923-1940)“, Karo archyvas, T. 29, 2014 m., p. 120-188.

${ }^{71}$ Lietuvos karine doktrina, D-LK-001. Vilnius: Lietuvos Respublikos krašto apsaugos ministerija, $2010 \mathrm{~m}$., p. 39.
} 
lizuotas užduoties vykdymas [...]“.72 Čia labai aiškiai matyti, kad tikslinis vadovavimas yra suprantamas instituciškai vadas paaiškina savo sumanymą ir suteikia pavaldiniams laisvę iggyvendinant paskirtą užduotị. Tokị požiūrị i tikslinị vadovavimą galima matyti nuo pat pirmųjų bandymų įvesti šią sampratą $\mathfrak{i}$ lietuvišką karinę praktiką. ${ }^{73}$ Tačiau tikslinis vadovavimas tai ne tik instituciniai sprendimai, kuriais yra decentralizuojamas ịsakymų vykdymas. Iš tiesų tai yra atskira, specifinè karinio rengimo ir kariavimo kultūra. Ji geriausiai mums yra žinoma kaip vokiškoji Auftragstaktik tradicija. O vokiškoji karinè tradicija garsejo savo dèmesiu karininkų intelektualiniam lavinimui, reikalavimu reguliariai užsiimti intelektualine refleksija, rašyti ekspertines publikacijas, dalyvauti diskusijose. $^{74}$ Taigi jeigu teigiame, kad tikslinis vadovavimas yra pamatinis mūsų karybos principas, tai reiškia, kad mes ji galèsime visiškai igyvendinti tik tada, kai turèsime intelektualiai aktyvius karininkus.

Kaip jau buvo pastebèta, karininkai nėra labai aktyvūs karinėje žiniasklaidoje. Kai kas teigtų, kad rimtų diskusijų reikètų ieškoti rimtesniuose leidiniuose, pvz., Lietuvos metinèje strateginèje apžvalgoje. Tačiau peržvelgus visus šio leidinio numerius tenka konstatuoti, kad per 13 metų šiame leidinyje buvo išspausdinti tik dviejų karininkų straipsniai. ${ }^{75}$ Kitame, Baltijos gynybos koledžo leidžiamame Baltic Security and Defence Review žurnale nuo 1999 m. buvo išspausdinti 6 karininkų straipsniai, iš kurių tik A. Litvaičio tekstas yra moksliškesnis. ${ }^{76}$ Tokie skaičiai verčia susirūpinti, kodèl karininkai nerašo straipsnių. Remiantis KAS duomenimis, nuo 1992 iki 2001 m. ịvairiuose užsienio

\footnotetext{
${ }^{72}$ Ibid.

${ }^{73}$ Konferencija „Teritorine gynyba: [konferencijos, įvykusios $2001 \mathrm{~m}$. birželio $11 \mathrm{~d}$., medžiaga] / Generolo Jono Žemaičio Lietuvos karo akademija. Vilnius: LKA, 2001 m., p. 23, 73; Sadaitis G., Tikslinis vadovavimas Lietuvos kariuomeneje, Karys, 2012, p. 20-23.

${ }^{74}$ Muth, Command Culture.Tex"'”number-of-pages":"x+366"'”edition":"1st ed.",'source":"Primo,"'eventplace":"Denton, Tex"'”ISBN":"978-1-57441-303-8'"'call-number":"U408",'shortTitle":"Command

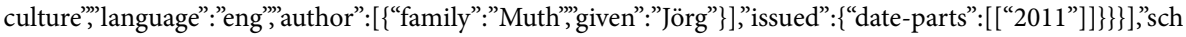
ema":"https://github.com/citation-style-language/schema/raw/master/csl-citation.json"\}

${ }^{75}$ Bagdonas G., Žvalgybos tarnybų ir politikos formuotojų santykiai: iššūkių ir jų priežasčių analizè, Lietuvos metiné strategine apžvalga 2008. Generolo Jono Žemaičio Lietuvos karo akademija, 2009, p. 33-50; Leika A., „Lietuvos vadovaujama provincijos atkūrimo grupe Afganistane - pasiekimai ir iššūkiai“, Lietuvos metine strategine apžvalga 2008. Generolo Jono Žemaičio Lietuvos karo akademija, 2009, p. 175-196. ${ }^{76}$ Alsauskas J., „The Baltic Naval Squadron - BALTRON“, Baltic Defence Review. No. 3, Volume 2000 m., pp. 33-37; Arūnas Stašaitis, „Lithuania's struggle against Soviet Occupation 1944-1953“, Baltic Defence Review. No. 3, Volume 2000, pp. 115-122; Jucius A., „Lithuanian Airspace Management in Times of Crisis and War“, Baltic Defence Review, No. 8, Vol. 2/2002, pp. 51-72; Zenkevičius G., „Rebuilding Afghanistan - Is That Post-Conflict Reconstruction?“, Baltic Security \& Defence Review Volume 9, 2007, pp. 28-56; Alasauskas A., Anglickis G., „On Baltic Deployment Experiences Lithuanian Lessons Learned From International Operations From 1994 to 2010“, Baltic Security and Defence Review Volume 12, issue, 2, 2010, pp. 134-158; Litvaitis A., „Challenges of Implementation of the Network Centric Warfare Tenets in Coalition Environment“, Baltic Security \& Defence Review, Volume 10, 2008, pp. 143-170.
} 
kariniuose koledžuose ir akademijose kursus ir mokslus baige 2685 karininkai (dauguma šių kursų buvo kalbų mokymasis). ${ }^{77}$ Karininkų karjeros koncepcijoje labai aiškiai parodoma, kad karininkai, siekdami aukštesnio laipsnio turi igyti ne tik atitinkamo lygio aukštajj išsilavinimą, bet ir lankyti ịvairaus lygio kursus tiek Lietuvoje, tiek užsienyje. ${ }^{78}$ Vadinasi, karininkai dali savo tarnybos laiko privaloma tvarka yra atitraukiami nuo kasdienių administracinių darbų. Jiems suteikiamos galimybès konceptualiau ịvertinti savo veiklos ir profesijos raidą. Žinant, kad tokiuose kursuose pagrindinè atsiskaitymo forma yra ịvairių rašto darbų rašymas, kyla natūralus klausimas, kodèl jų pagrindu karininkai neparengia publikacijų karinės žiniasklaidos leidiniams. Tokia praktika yra taikoma daugumoje Vakarų valstybių.

Lietuvoje pirmuosius žingsnius žengia dar viena vakarietiškos karinès refleksijos tradicija: operacijų dalyvių memuarų ir atsiminimų leidyba. Šiuo metu turime dviejų puskarininkių atsiminimus apie jų tarnybą Afganistane ir Irake. ${ }^{79}$ Tačiau visa tai vyksta sunkiai, buvo prieita net iki teisminių procesų ${ }^{80}$

Kalbant apie knygas, būtų galima paminèti Karo akademijos išleistą monografiją Profesionalioji kariuomenè: Vakaru šaliu patirtis ir perspektyvos, kurioje 3 straipsnių autoriai buvo karininkai. ${ }^{81}$ Dar viena demesio verta knyga yra S. Knezio Čečėnijos karas. Ji išsiskiria tuo, kad jos autorius knygos rašymo laikotarpiu užèmè svarbias karines, o po to ir civilines pareigas. Kaip teigè pats autorius, „galima kurti ịvairias teorijas apie mažos valstybės gynybos organizavimą, galimus jos variantus, strategiją ir taktiką [...], bet ypač pravartu apmąstyti tai, ką matome tikroveje “. ${ }^{82}$ Šioje knygoje autorius atlieką tikrai neblogą operacinio ir taktinio lygmens mūšių analizę, taip parodydamas ne vieną būdą, kaip galima vykdant teritorinę gynybą priešinantis Rusijai. Praktinė knygos intencija yra labai aiški, nes tuo metu Lietuvoje vyksta diskusijos apie tai, kokị teritorinės gynybos modelị reikètų taikyti. Tačiau tenka konstatuoti, kad vèlesnès karininkų kartos nepasekè S. Knezio pavyzdžiu ir tikrai mažai rašè, tyrè naujausius karinius konfliktus ir bandè pritaikyti jų patirti Lietuvoje.

Šioje vietoje situacijos skurdumą vèl geriausiai išryškina palyginimas su tarpukario Lietuva. $1994 \mathrm{~m}$. buvo iš naujo perleista tarpukario gen. št. mjr. V. Bul-

\footnotetext{
77 Radvilas G., „Moderni kariuomenė išsilavinę karininkai“, Kardas, 2012, Nr. 1., p. 52.

${ }^{78}$ Karininkų karjeros koncepcija, Lietuvos Respublikos krašto apsaugos ministro $2012 \mathrm{~m}$. kovo $1 \mathrm{~d}$. isakymas Nr. V-219.

${ }^{79}$ Kuckailis E., Trispalvio Erelio skrydis; Maliauskas S., Operacijoje Irako laisve

${ }^{80}$ Dèl autorių turtinių teisių gynimo, Byla 2-2095-886/2014, http://eteismai.lt/byla/7619905374869/22095-886/2014

${ }^{81}$ Novagrockienė J., sudar., Profesionalioji kariuomene: Vakarų šaliu patirtis ir perspektyvos Lietuvoje . Vilnius: Generolo Jono Žemaičio Lietuvos karo akademija, 2005).

${ }^{82}$ Knezys S., Čečenijos karas. Vilnius: Aidai, 1997, p. 9.
} 
vičiaus knyga Karinis valstybès rengimas. ${ }^{83}$ Nors daugeliu atveju šis autorius yra minimas, kai kalbame apie tautos dvasini pasirengimą kautis, iš tiesų jo veikalas, visų pirma, yra tikrai aukšto lygio karinès minties refleksija. V. Bulvičius demonstruoja puikų pagrindinių vakarietiškų karo teorijų ir koncepcijų išmanymą. Iš tiesų šiu eilučių autoriui Bulvičiaus interpretacijos sukèlè didesnị norą pradèti rimtą teorinę diskusiją nei visi tekstai, parašyti Lietuvoje po 1990 m. Tenka konstatuoti, kad po nepriklausomybès atkūrimo nei kariškiai, nei civiliai nesugebèjo parengti tokios publikacijos, kurioje būtų kokybiškai analizuojamos naujausios šių dienų karinès teorijos.

Turbūt arčiausia prie tokio lygio diskusijos buvo priartèta 2008-9 m., kai ị lietuvių kalbą buvo išverstas Clausewitzo veikalas Apie karą ${ }^{84}$ Clausewitzo knygos rašymo, leidimo ir vertimo istorija rodo, kad tai gana sunkiai įkandamas teorinis veikalas.$^{85}$ Kadangi lietuviškas vertimas neturi jokio įvadinio straipsnio, sunku spręsti, kokia buvo šio leidimo istorija, kuris Clausewitzo leidimas (1832 ar $1853 \mathrm{~m}$.) buvo verčiamas. Visa tai yra svarbu, nes nuo to priklauso, kokios formuluotés yra naudojamos, o tai savo ruožtu veda prie subtilaus, bet kitokio karo kaip reiškinio supratimo. Skaitant lietuviškajj vertimą susidaro ịspūdis, kad tai yra labiau filologinis, nei ekspertinis vertimas. Todèl reikia atsargiai vertinti ir remtis šia versija. Kita vertus, pats knygos išvertimo faktas laikytinas pozityviu ženklu ir ịrodymu, kad karo teorijos laukas Lietuvoje nèra apleistas.

Su Clausewitzu yra susijusi ir turbūt kone vienintelè karo teorijos temai skirta publikacijų serija karinejje žiniasklaidoje. Kariūno žurnale ilgametis KAS ir LKA darbuotojas A. Kanauka publikavo daug straipsnių, skirtų Clausewitzo idèjoms aptarti. ${ }^{86}$ Šie straipsniai yra labiau edukacinio, o ne mokslinio pobūdžio, nes skirti daugiausia kariūnams. Todèl autorius juose supaprastintai pateikia prūsų mąstytojo mintis, aiškiai pabrèždamas karo priklausymą nuo politikos idejją. Tačiau užduokime sau klausimą: ką apie lietuvišką karinès minties refleksiją rodo faktas, kad vienintele pagrindinio Vakarų karo mąstytojo idejjų apžvalga pateikiama studentiškame leidinyje?

Taigi apibendrinant tenka konstatuoti, kad Lietuvoje karininkija per visą nepriklausomybès laikotarpi dejjo mažai pastangų viešoms ekspertų dis-

\footnotetext{
${ }^{83}$ Bulvičius V., Karinis valstybès rengimas.

${ }^{84}$ Carl von Clausewitz, Apie kara. Vilnius: Generolo Jono Žemaičio Lietuvos karo akademija, 1 D., 2008 m., 2 D., 2009.

${ }^{85}$ Strachan H., Herberg-Rothe A., Clausewitz in the Twenty-First Century, pp. 57-73.

${ }^{86}$ Kanauka A. V., „Pusvalandis su Klauzevicu“, Kariūnas, 2009 m. Nr. 3 (102), pp. 25-29; Kanauka A. V., „Klauzevicas ir mažieji karai“, Kariūnas, 2010, Nr. 1 (104), pp. 28-33; Kanauka A. V., „Frydrichas II ir Napoleonas per Klauzevico prizmę“, Kariūnas, 2010, Nr. 2 (105), pp. 26-29, 2010, Nr. 3 (106), pp. 19-25.
} 
kusijoms palaikyti, idejjų sklaidai, kritinei refleksijai apie savo profesiją ir pagrindinį profesijos objektą - karą. Šiuo atveju susidaro komplikuota situacija. Nematant kariuomenejje vykstančių diskusijų pradeda kilti abejonių dèl karininkų kompetencijos. Kaip ir ką karininkai žino apie karą, karybą, kintančias jos formas ir būdus? Visa tai veda prie dar reikšmingesnès problemos. Nematydami karininkijos viduje vykstančių diskusijų civiliai susiduria su sunkumais bandydami suprasti karinị mentalitetą, požiūrị i k karą ir politiką. Kitaip tariant, užtikrinti civilinę kontrolę yra sudètinga. Atsiranda intelektualinis ir koncepcinis atotrūkis tarp civilių ir kariškių. ${ }^{87}$

İvairių diskusijų ir pokalbių metu buvusi ir esama KAM ir kariuomenès vadovybė ne kartą tvirtino, kad nedraudžia karininkams rašyti ekspertinių publikacijų, organizuoti teminių diskusijų. Tačiau, kaip rodo duomenys, to nepakanka, kad karininkai taptų aktyvesni. Kai kurie kalbinti karininkai teige, kad 2002 m. žiemą kilęs politinis skandalas dèl tuomečio Lietuvos kariuomenès vado gen. mjr. J. Kronkaičio kalbos išeivijos renginyje naujajai karininkijos kartai tapo pavyzdžiu, ko negalima daryti. J. Kronkaitis buvo kaltinamas politikavimu, kalbejjimu apie reikalus, apie kuriuos karininkas neturètų iš viso kalbèti viešumoje.$^{88}$ Paprastai tariant, karininkai išgirdo žinią - nori dirbti, neišsišok viešumoje. Taigi šioje vietoje suveikia Huntingtono civilių ir kariškių santykių modelio logika: civiliai užsiima politika, o kariškiai vykdo jiems pavestas karines užduotis. Tačiau, kaip galima turèti gerai suformuluotą strategiją, jeigu mes nemokome ir neleidžiame karininkams kalbèti? Kaip jie mums sugebès paaiškinti karines subtilybes, jeigu nèra sudarytos sąlygos tam daryti. ${ }^{89}$

Visgi visoje šioje istorijoje negalima visos kaltès versti karininkijai. Ne ką mažesnių bẻdų ir trūkumų turi ir civiliai. Peržvelgus Lietuvos mokslinius leidinius tenka konstatuoti, kad mūsų krašte karo studijos nèra populiari disciplina. Mokslininkų, kurie tyrinètų Lietuvos ir kitų kraštų karinę mintị, karinių pajègų raidą, kariuomenès ir visuomenès tarpusavio sąveiką yra labai nedaug: J. Novagrockienè, G. Miniotaitè, G. Vitkus, K. Paulauskas, T. Jermalavičius, E. Račius, M. Šešelgytè, V. Urbelis, D. Šlekys, K. Aleksa,

\footnotetext{
${ }^{87}$ Feaver D., Kohn R. H., Soldiers and Civilians the Civil-Military Gap and American National Security.

${ }^{88}$ Prezidentūra: kariuomenès vadui politikuoti nedera. http://www.delfi.lt/news/daily/lithuania/prezidentura-kariuomenes-vadui-politikuoti-nedera.d?id=792966; Kronkaitis J., „Lietuvos vaidmuo Vakarų Europoje“, 35-ųjų politinių studijų, vykusių Los Andžele (JAV), pranešimas. http://www.xxiamzius.lt/ archyvas/priedai/horizontai/2002_6_6/p5_1.html.

${ }^{89}$ Diskutuojat su įvairiais karininkais ir politikais dažnai galima išgirsti ir dar vieną priežastị, kodèl karininkija nediskutuoja viešai. Teigiama, kad taip darant bus atskleistos tam tikros detalès, kurių neturètų žinoti Rusija.
} 
B. Jasiukènaite. ${ }^{90}$ Daugiausiai mokslinių straipsnių, vienaip ar kitaip susijusių su karo tematika, yra spausdinama jau minètoje Lietuvos metinejje strategineje apžvalgoje. Vieną kitą straipsnị, bent truputị susijusị su karine tematika, galima rasti ir kituose Lietuvos periodiniuose moksliniuose leidiniuose ar knygose. Tačiau tai labiau išimtiniai atvejai, o ne norma.

Peržvelgus ir perskaičius publikuojamus straipsnius būtų galima teigti, kad tekstų, skirtų tik karinei tematikai nèra daug. Iš aukščiau minètų mokslininkų, didžioji dalis karinę tematiką arba aptaria tik kaip šalutinę temą. Dažniausiai tai būna tekstai apie Lietuvos ar kitų valstybių saugumo sampratą, strateginę kultūrą ar strateginị mąstymą. ${ }^{91}$ Šios temos susijusios su karo studijų disciplina, tačiau akademiniame pasaulyje jos nèra priskiriamos tai pačiai grupei. Iš karinès tematikos tekstų daugiausiai yra straipsnių iš karo sociologijos srities: civilių ir kariškių santykių būklè Lietuvoje, kariuomenès ir visuomenès tarpusavio sąveika, karinio veiksnio svarba lietuviškajam identitetui ir misijos Afganistane analize..$^{92}$ Netiesiogiai ši tema taip paliečiama tekstuose apie terorizmą. ${ }^{93}$ Karinès minties tema giliau ir plačiau yra tyrinejjama ir analizuojama tik

\footnotetext{
${ }^{90}$ Gailiūnas E., „Terorizmas ir partizaninis karas - dvi sukilimo formos. Politologija, 2010, Nr. 1, p. 98-124; Urbelis V, Strategija jos elementai ir sąvokos. Politologija, 2001, Nr. 4, p. 53-81; Račius E., Maskaliūnaitė A., Šlekys D., Urbelis V., Tarptautinès antiteroristinés kovos iššükiu Lietuvai analizè. Vilnius: Vilniaus universiteto leidykla, 2007; Šlekys D., "More than semantics: the difference between the concepts of "Military Revolution" and "Revolution in militarry affairs"'. Lithuanian political science yearbook 2007, p. 51-87; Molis A., "Baltic Military Cooperation: Past, Present and the Future". Lithuanian foreign policy review, 2009, Nr. 22, p. 24-47; Novagrockienè J. (atsakingoji redaktorè), Profesionalioji kariuomené: Vakaru šaliu patirtis ir perspektyvos Lietuvoje. Vilnius: Generolo Jono Žemaičio Lietuvos karo akademija, 2005; Šešelgytė M., „Security culture of Lithuania“. Lithuanian foreign policy review, 2010, Nr. 24, p. 23-40; Jakniūnaitè D., Paulauskas K., Beieškant NATO Lietuvoje: pasiekimai, nesèkmès, perspektyvos. Vilnius: Vilniaus universiteto leidykla, 2010.

${ }^{91}$ Šešelgyte M., „NATO reagavimo pajègų ir ES greitojo reagavimo pajëgų veiklos perspektyvos", Lietuvos metine strateginé apžvalga, 2003, p. 103-130; Aleksa K., Karinio pokyčio poveikio tarptautinei sistemai interpretacijos. Lietuvos metinè strategine apžvalga 20092010, 2010, p. 9-28; Paulauskas K., NATO šiandien: pasiklydę transformacijoje?. Lietuvos metinè strategine apžvalga 2009-2010, 2010, p. 29-52; Zapolskis M., NATO transformacijos scenarijai, Lietuvos metine strateginé apžvalga 2009-2010, 2010, p. 53-76; Zapolskis M., NATO 1999 ir 2010 m. strateginių koncepcijų lyginamoji analizè. Lietuvos metiné strateginé apžvalga 2011-2012, 2012, p. 33-58.

${ }_{92}$ Miniotaite G., Pilietinis pasipriešinimas Lietuvos saugumo ir gynybos sistemoje: raida ir perspektyvos. Lietuvos metiné strateginé apžvalga 2003, 2004, p. 195-209; Miniotaité G., Lietuvos saugumo ir gynybos politika: raida ir perspektyvos, Lietuvos metiné strategine apžvalga 2006, 2007, p. 161174; Miniotaitė G., Kariuomenès modelio konstravimas Lietuvos politiniame diskurse, Lietuvos metiné strateginè apžvalga 2008, 2009, p. 197-214; Novagrockienė J., Kariuomenès transformacija XXI amžiuje: Lietuvos atvejis. Lietuvos metinè strateginé apžvalga 2004, 2005, p. 197-214; Novagrockienė J., Kario profesijos įvaizdis Lietuvoje; karių, visuomenès ir jaunimo požiūris. Lietuvos metine strateginé apžvalga 2009-2010, 2010, p. 193-216; Budginaitė J., „Lietuvos provincijos atkūrimo grupè Afganistane: tinklaveikos fenomenas“, Lietuvos metiné strateginé apžvalga 2012-2013, 20-13, pp. 227-248; Maskoliūnaite A., Noras pasidalyti naštą su partneriais? Lietuvos sprendimo vadovauti provincijos atkūrimo grupei Afganistane vertinimas Lietuvos metiné strategine apžvalga 2013-2014, 2014 m., pp. 213-232.

${ }^{93}$ Dranseikaitè E., Globalizacija ir naujo tipo gressmès; Račius E., Terorizmo globalumas.
} 
78 straipsniuose. ${ }^{94} \mathrm{Nè} \mathrm{vienas} \mathrm{iš} \mathrm{jų} \mathrm{nèra} \mathrm{skirtas} \mathrm{aptarti} \mathrm{tik} \mathrm{Lietuvos} \mathrm{karinès} \mathrm{minties}$ būklei. Juose yra aptariamos ịvairios Vakaruose vykstančios diskusijos ir tik dalyje straipsnių trumpai pažvelgiama, kokị poveikị tai turi procesams Lietuvoje.

Atsižvelgiant ị tai, būtų galima teigti, kad skurdi refleksija apie karinius reikalus karinèse pajėgose neturètų stebinti, jeigu civiliai patys nèra labai aktyvūs šiose diskusijose. Sunku reikalauti iš karininkų rimtų, ekspertinių publikacijų, jeigu nèra civilių akademikų ar žurnalistų, kurie jiems galètų padèti ir patartų šiais klausimais. Šiuo atveju bandyti suprasti ir žinoti, o ką apie karybą galvoja mūsų karininkija yra sudètinga ne tik dèl problemų kariuomenès viduje, tačiau ir dèl pačios civilinès erdvès pasyvumo. O tai reiškia, kad siekiant užtikrinti konceptualinę civilinę kontrolę ir suprasti, apie ką galvoja mūsų karininkija yra sudètingas uždavinys.

$2014 \mathrm{~m}$. ̣̇vykiai parodè kaip sudètinga ịveikti visus šiuos barjerus. Dèl ịvykių Ukrainoje suintensyvejjo visuomenès, politikų, žiniasklaidos dèmesys karinių pajègų atžvilgiu. Žiniasklaida mirgèjo nuo komentarų apie hibridinę karybą, žaliuosius žmogeliukus, Lietuvos karinius ịsigijimus, NATO vaidmenị. Stebint visą procesą buvo matyti, kad kariuomenès atstovai sunkiai prièmé padidejjusị susidomèjimą, kèlimą klausimų temomis, kurios anksčiau buvo laikomos išimtinai kariškių reikalu. O tuo pačiu metu civiliai ekspertai daugeliu atveju pateikdavo gana supaprastintą ir dažnai klaidinančią įvykių analizę.

Tais pačiais metais ịvyko ir tam tikras proveržis karo studijų srityje. Ji galima sieti su trimis publikacijomis. Pirmosios autorius, žurnalistas A. Matonis išleido Lietuvos specialiụjų operacijų pajègų istorijos knygą ${ }^{95}$ Nors tai nèra mokslinè publikacija, atsižvelgiant ị tirtų pajègų specifiką, tai yra didelis žingsnis link glaudesnio civilių ir kariškių bendradarbiavimo. Jeigu galime leisti knygas apie Specialiųjų operacijų pajègas, tai laikui bėgant mažiau bijosime kalbèti ir diskutuoti apie karinius planus ir strategijas. Antroji publikacija skirta susisteminti informaciją apie konfliktus, vykusius Lietuvoje nuo 1816 m., ir šiais duomenimis papildyti ir išplèsti (tiek empiriškai, tiek teoriškai) ịtakingą JAV mokslininkų vykdomą „Karo koreliatų“ (angl. Correlates of War) projek-

\footnotetext{
${ }^{94}$ Šlekys D., Amerikietiškosios kariavimo tradicijos svarba ir keliamos problemos, Lietuvos metine strategine apžvalga 2007, 2008, p. 25-48; Jermalavičius T., „Globalus karas su terorizmu“": iš naujo atrasta sukilimo ir kontrsukilimo teorija. Lietuvos metiné strategine apžvalga 2006, 2007, p. 25-39; Jasiukènaitè B., „Naujųjų karų koncepcija: pagrịstumo klausimas”. Lietuvos metiné strateginé apžvalga 2010-2011, 2011, p. 23-38; Maliukevičius N., Karinis konfliktas informacijos amžiuje ir Lietuvos pasirengimas. Lietuvos metine strategine apžvalga 2003, 2004, p. 53-72; Šataite E. E., „Taikos atstatymo operacijos: Bosnijos ir Hercogovinos atvejis Lietuvos metine strateginé apžvalga 2008, 2009 m., pp. 89-111; Gailiūnas E., Šlekys D., „More than semantics“; Urbelis V., Lietuvos atgrasinimo strategija Lietuvos metine strateginé apžvalga 2005, 2006 m, pp. 245-272.

${ }^{95}$ Matonis A., Gabrieliaus kariai.
} 
tą. ${ }^{96}$ Šis Vakarų mokslininkų tęstinis projektas yra vykdomas nuo 1970 m. ir jo tikslas yra surinkti ịvairią empirinę medžiagą apie visame pasaulyje vykusius konfliktus, kuri leistų daryti ịvairius teorinius apibendrinimus. Nors tiesiogiai su karo teorija ši publikacija nesusijusi, tačiau tai reikšmingas žingsnis plètojant karo studijas Lietuvoje. Kita vertus, šios publikacijos rengimo metu kilę teoriniai ir metodologiniai klausimai sulaukè užsienio ekspertų dèmesio ir sukẻlè mokslinę diskusiją ${ }^{97}$ Galiausiai trečioji publikacija yra skirta tarpukario Lietuvos karinès galios analizei..$^{98}$ Tai pirmasis rimtas sistemingas mokslinis veikalas, skirtas tarpukario karinių planų, doktrinų, tradicijų analizei. Šios aukšto lygio mokslinès knygos autorius sąmoningai bando susieti praeities pamokas su šiu dienų Lietuvos gynybos dilemomis.

Tačiau pabaigai reikia pabrěžti, kad šis pastarujų metų kokybinis šuolis karinès refleksijos srityje negali kompensuoti pirmųjų skurdžių 24 nepriklausomybės metų. Mažai specialistų tiek akademiniuose sluoksniuose, tiek žiniasklaidos srityje sudaro sąlygas sekti ir kontroliuoti karinę dimensiją konceptualiu lygmeniu. Karinėse pajègose formuluojamos koncepcijos nesulauké kokybiškos ekspertinès civilių revizijos, todèl diskurso lygmenyje dominuoja karinè versija. Taigi jeigu manome, kad efektyvūs civilių ir kariškių santykiai pirmiausia pasižymi geru strategijų formulavimu, o tai reiškia, kad egzistuoja suvokimas ir refleksija apie karo prigimtį ir kintančią karybą, tai tokiu atveju Lietuvos civilių ir kariškių santykiai turi nemenkų trūkumų. Pačios ekspertizès egzistavimas yra tik dalis viso paveikslo. Jeigu egzistuoja refleksija, vadinasi,egzistuoja ir tradicija išklausyti ir priimti kitokią nuomonę, poziciją. Tai sudaro aplinką atsirasti konstruktyviam, atviram pokalbiui, diskusijai, kurioje dalyvauja ir visuomenè. Šiuo atveju Lietuva iš tiesų tik dabar pradeda žengti žingsnius šia kryptimi.

\section{Išvados}

Civilių ir kariškių santykiai ir kontrolè susideda ne tik iš tinkamo teisinio reguliavimo, funkcionuojančio biurokratinio aparato, karių nedalyvavi-

\footnotetext{
${ }^{96}$ Vitkus G., Lietuvos karai: Lietuvos XIX-XX a. nacionaliniu karu sisteminé-kiekybiné analizé.

${ }^{97}$ Vitkus G., 'Forest Brothers' And The Consequences Of Metropole-Periphery Distinction Elimination In The 'Correlates Of War' Typology, Journal of Baltic Studies, 2012 vol. 43, no 4, p. 515-527; Sarkees M. R., "Response to the ""Forest Brothers" and the Consequences of Metropole-Periphery Distinction in the "Correlates of War" Typology". Journal of Baltic Studies, 2012 vol. 43, no 4, p. 528-538; Vitkus G., "Once more on Advantages and Disadvantages of Metropole-Periphery Distinction Elimination: A Rejoinder", Journal of Baltic Studies, vol. 43, no 4, p. 539-544.

${ }^{98}$ Jokubauskas V., Mažujų kariuomeniu galia ir paramilitarizmas.
} 
mo politinèje veikloje. Ne mažiau svarbų vaidmenị vaidina ir tai, kaip ir kokia institucijų ribojama veikla vykdoma. Kariuomenès užduotis yra ginti valstybę. Tam yra būtina efektyvi strategija, kurios nepavyks parengti, jeigu nebus išpildytos dvi sąlygos. Pirma - kariuomenès atstovai turi būti traktuojami kaip dialogo partneriai, o ne kaip pavaldiniai. Šiuo atveju civiliai turi leisti ir nebausti karininkų, už ekspertines diskusijas viešojoje erdveje. Antra - geros ekspertinès diskusijos nebus, o tuo pačiu ir kokybiškos diskursyvinès kariškių kontrolès, jeigu nebus palaikoma intelektualinès refleksijos tradicija. Karininkas, kuris nemoka ir negeba analizuoti ir diskutuoti apie naujausių konfliktų specifiką ir dinamiką, gali pridaryti daug žalos, nes gali pateikti klaidinančias rekomendacijas. Politikai ir visuomené, negebanti suprasti, ar kariuomenès rekomendacija yra kokybiška ar ne, rizikuoja priimti blogus, brangiai kainuojančius ir papildomą riziką sukelsiančius politinius sprendimus.

Atkūrusi nepriklausomybę Lietuva perèmè jai siūlomas gerąsias vakarietiškas praktikas. Jomis remiantis buvo kuriama demokratinè civilinè karinių pajègų kontrolès sistema. Tačiau vykstant procesui buvo sukurti struktūriniai apribojimai ir kliūtys kokybiškai intelektualinei refleksijai. Šiuo metu Vakaruose prasidejusi diskusija rodo, kad tie modeliai, kuriais rèmèsi visos demokratinès valstybès, turi rimtų trūkumų ir būtina atlikti esminę jų reviziją. Būtų galima teigti, kad mūsų šalies situacija labai gerai atskleidè vakarietiškų modelių pritaikymo spragas ir pritaikymo ribas. Todèl šiuo atveju Lietuvos atvejo analizė gali būti naudinga ne tik konkrečioms politinėms rekomendacijoms formuluoti, tačiau ir praturtinti mokslinę diskusiją, kaip turètų būti užtikrinama gerai funkcionuojanti civilinè kariškių kontrolè. 